UC-NRLF

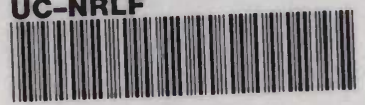

\title{
B 3135241
}

InE IIUUNI'AIN TREES

SOUTHERN CALIFORNIA

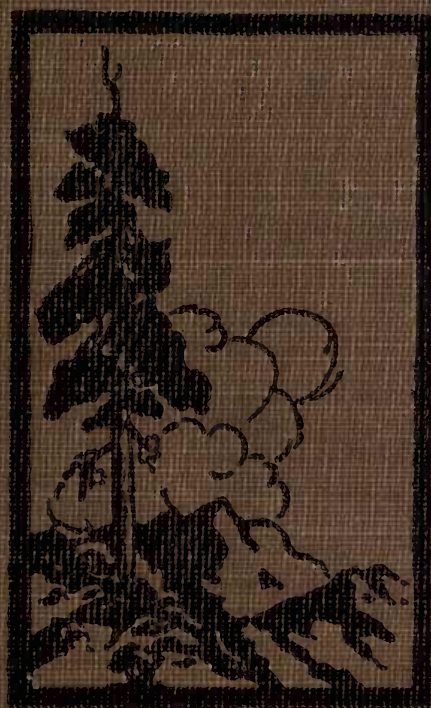

EDMUNO C. JAEGER 

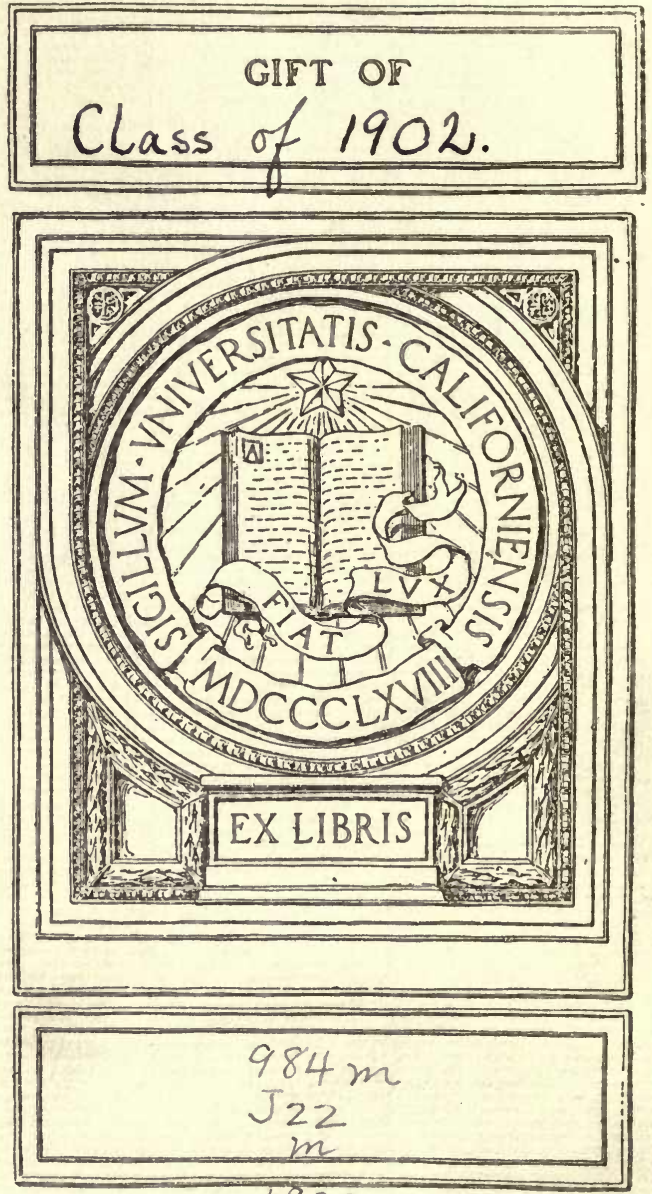

1920 


THE MOUNTAIN TREES

OF SOUTHERN CALIFORNIA 



\section{The Mountain Trees}

.. of ..

\section{Southern California}

A Simple

Guide-Book for Tree Lovers

EDMUND C. JAEGER, B.Sc.

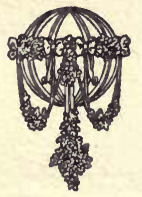

Illustrated with Line Drawings by the Author 
Copyright, 1920

By Edmund C. Jaeger

First Issue - December, 1919
Reprinted - September, 1920

All correspondence should be addressed to

EDMUND C. JAEGER

1462 West Sixth Street

Riverside - - California

Printed by

Post Printing \& Binding Co.

Pasadena, California

$$
\text { ceass of } 1902
$$

$1+\cdots$ 


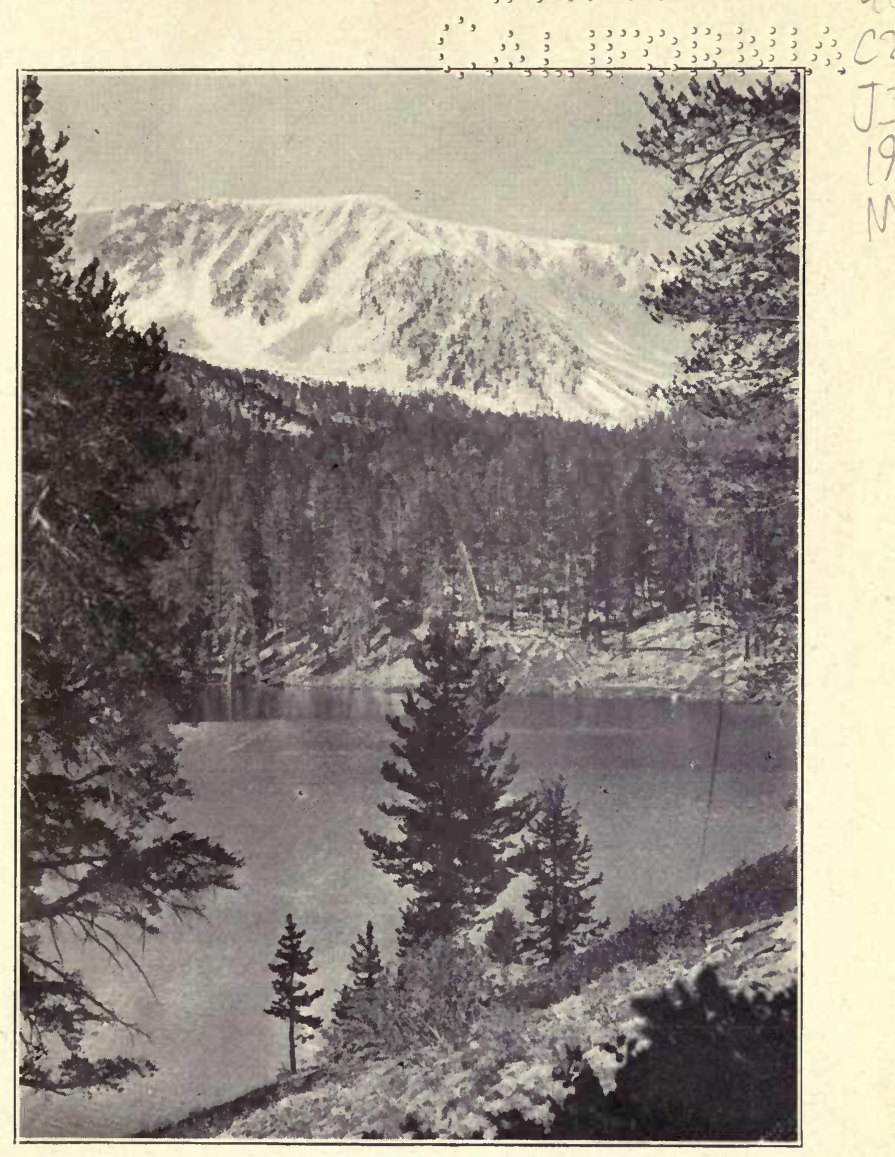

DRY LAKE AND SAN GORGONIO PEAK

The heavy forest across the lake consists of Lodge-pole and Limber Pines. The stunted trees near timber line which here occurs at about 11,000 feet are mostly Limber Pines. Photographed July lst.

\section{ᄂ.51374}




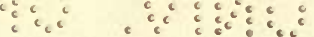

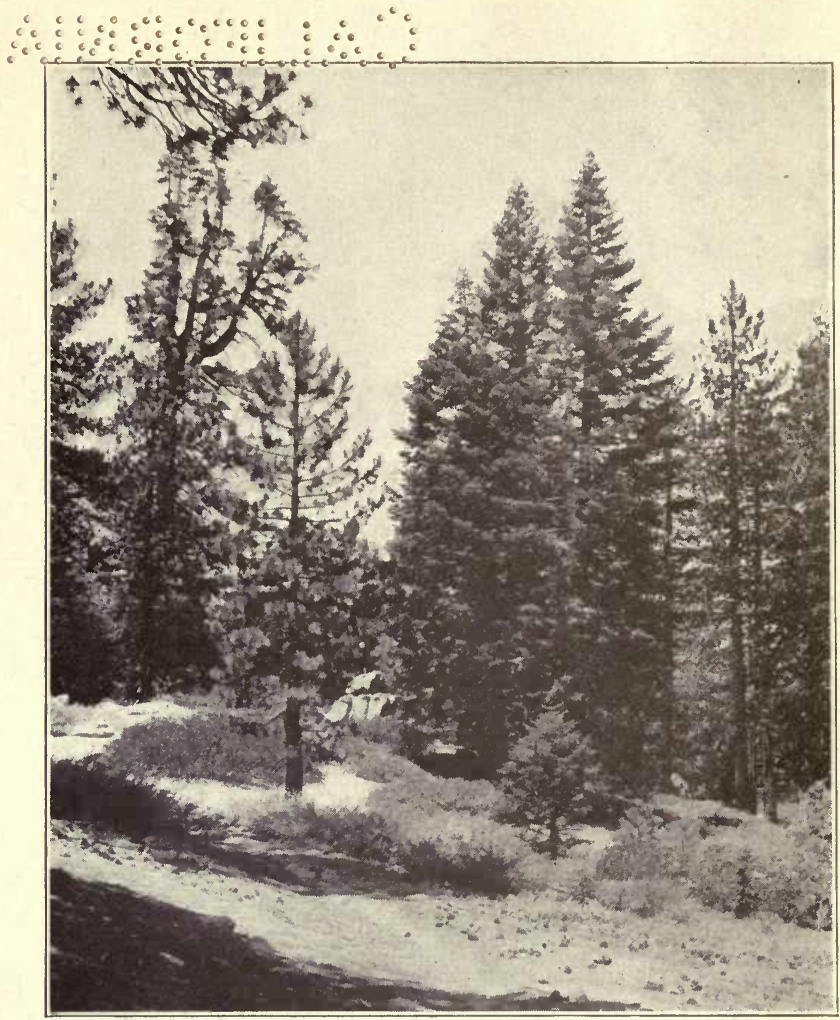

A GROUP OF YOUNG WHITE FIRS

The low, mat-like, twiggy shrub is Buck-brush (Ceonothus cordulatus), a characteristic plant of the higher altitudes. 
$\because \vdots \because \quad \vdots \vdots \vdots \because \vdots \vdots \vdots$

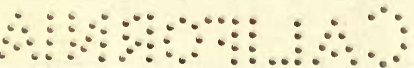

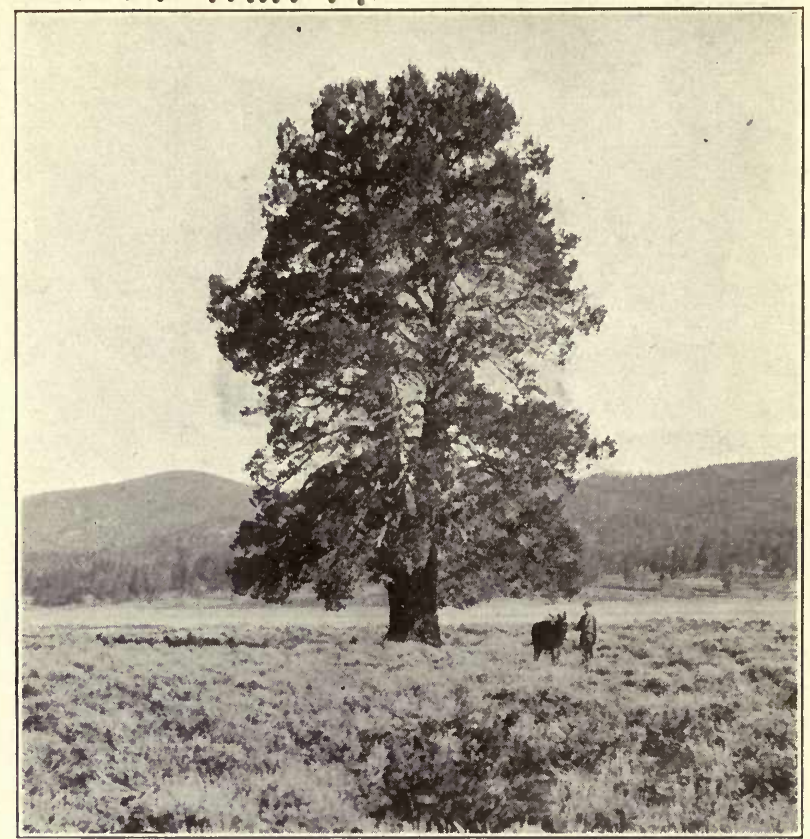

WESTERN JUNIPER NEAR BEAR LAKE

Two other Junipers occur within our region-the Scrub or California Juniper ( $J$. californica) and the Utah Juniper ( $J$. utahensis). Both are shrubs restricted to desert regions and are therefore not likely to be confused with the Western Mountain Juniper. 


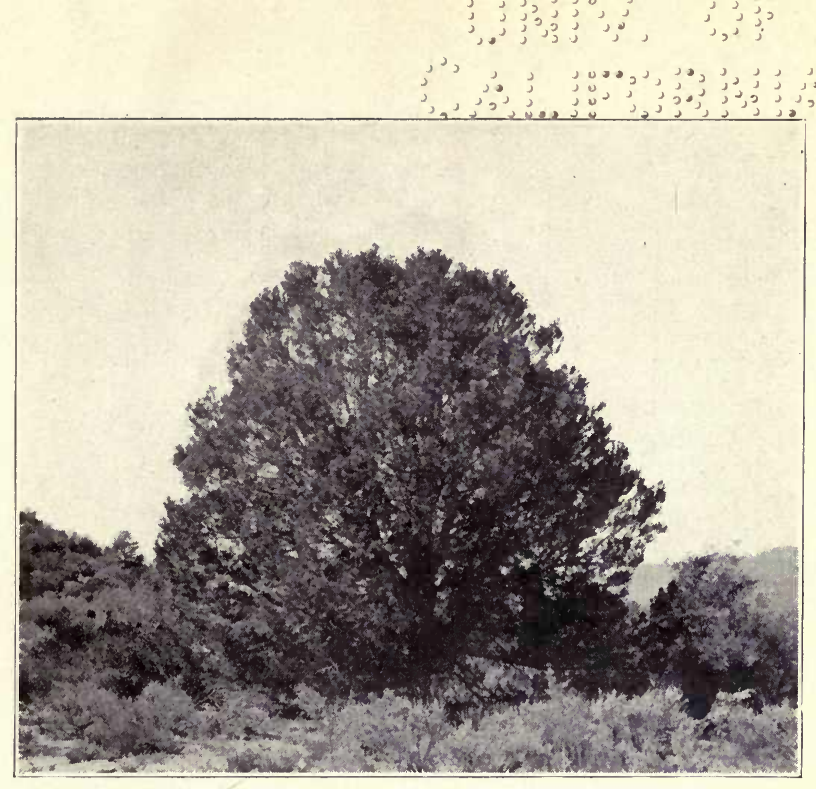

\section{FOUR-LEAF OR PARRY PINE}

Young trees and those growing in open places are generally quite symmetrical in form. The older specimens, 20 to 30 feet high, with their black-barked, much divided and gnarled branches must be rated as among our most beautiful coniferous trees. In the upper reaches of Horse Canyon near Van De Venter's Flat in the San Jacinto Mountains are probably the finest specimens and greatest numbers of individuals to be found in one locality north of the Mexican boundary. 
TO M Y MOTHER Who in early youth sent me out to play among the wild gardens of flowers and to seek the companionship of noble trees. 


\section{FOREWORD}

This book is written for those who want to know our mountain trees and yet know little about technical botany. It is the "green-horn's" own book, and yet the author believes it has much of interest to all students of trees. To enjoy it best you must carry it into the forest and read the descriptions with the living trees before you. It is then that their features take definite form in the mind, and their spiritual values become apparent. I urge all to make careful and repeated study of the drawings, as it is the surest means of early recognition of the different trees. 
By a tree is meant any woody plant with well-defined central stem or trunk and a height of at least 15 feet. All woody plants which retain their lateral shoots so that their branches are formed near the ground and are less than 15 feet high are properly called shrubs and are not considered in this book. The reader will do well to bear this in mind. Arbitrarily the author has considered as mountain trees only those occurring at an elevation above 3500 feet.

In dealing with the pines, I have arranged them in the order of the number of needles in a bundle, an easy classification which will be helpful to many. Since each species bears in its bark, leaf, and cone the most prominent distinguishing characters, synoptic descriptions of these are given at the beginning of each sketch.

The valuable assistance of $\mathrm{Mr}$. Charles F. Saunders and Mr. S. B. Par- 
ish in making suggestions is cordially acknowledged, and thanks are returned to all others who in any way have helped in the preparation of this volume.

\section{EDMUND C. JAEGER.}

Palm Springs, California. 

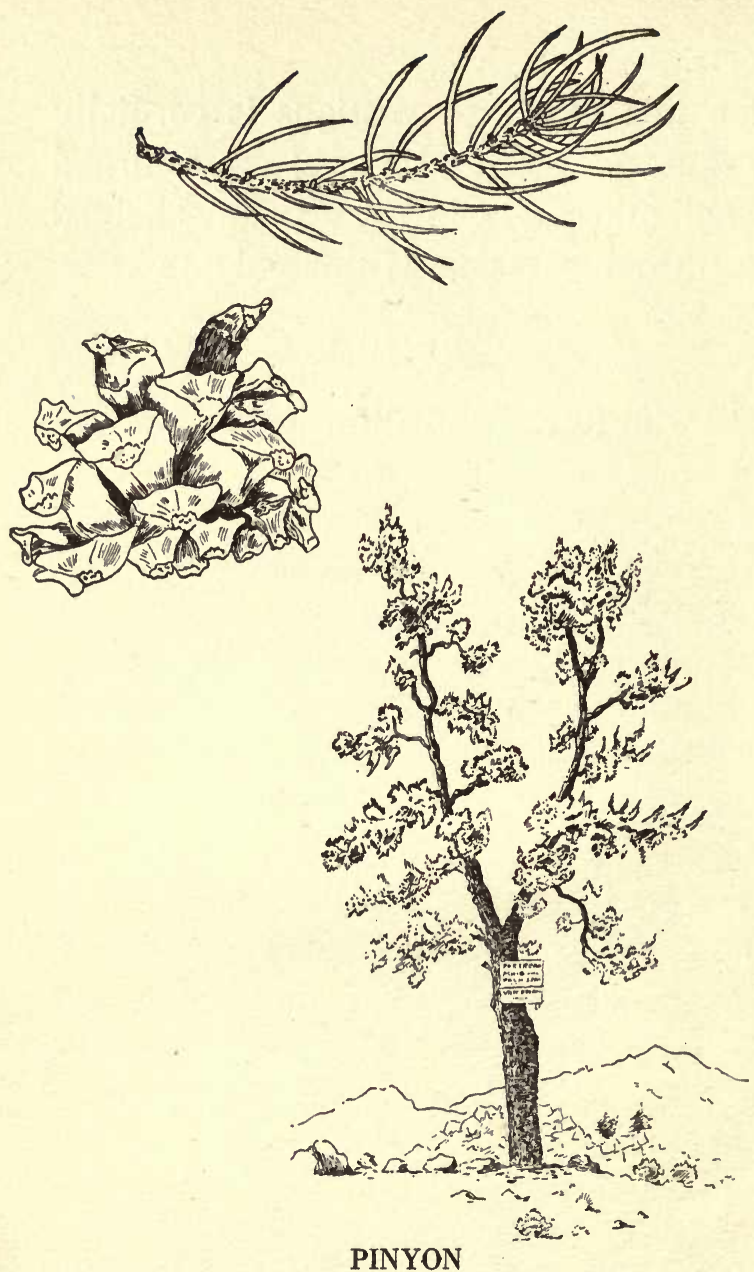

1. Branch and cone (one-fourth natural size)

2. The sign-board Pinyon at the head of the Van De Venter Trail, Santa Rosa Mountains 


\section{ONE-LEAF Pinyon}

Pinus monophylla TORR \& FREM.

BARK-Dark brown, reddish brown or almost black, finely and irregularly fissured, nearly an inch thick.

LEAvEs-Single (or very occasionally double), $1 \frac{1}{4}$ to $2 \frac{1}{4}$ inches long, stiff, curved upward and sharppointed.

Cone-Almost globular, chocolate brown, $1 \frac{1}{2}$ to $2 \frac{1}{2}$ inches long, made up of few thick scales with blunt summits and bearing a minute prickle, exceedingly resinous; seeds wingless.

This humble dweller of the desert mountain slopes is, as a furnisher of food, one of the most valuable of the pines. It is the Indians' own tree, and the thousands of acres of Pinyon forests are his wild orchard from which for ages he has depended for a considerable portion of the winter's food supply. Some of the oldest and best defined trails leading out of the deserts and into the mountains were those which led to the forests of Pinyons. No doubt it was a beautiful sight to watch the bands of gaily dressed Indians as they made their way at autumn time over these ancient trails and stopped at night at the camps 
on the way up the mountains. The remains of the old blackened caves, near some lone spring where the camps were made at the end of the day's journey are yet found, and the mortars where the daily portions of acorn meal were ground are still waiting to be used as of old.

Once the nutting grounds were reached, the cones were beaten from the trees with long poles, gathered in piles, and light brush fires built over them. The heat caused the scales of the cones to gape open, thus allowing the fat, brown, speckled nuts to be plucked from their pockets. Sometimes the cones were beaten from the trees in midsummer while yet green, roasted, and then split open with a hatchet and the nuts extracted. In either case the nuts were generally roasted before being eaten, a process which added much to their flavor. According to Dr. Barrows, the Cahuilla Indians of the Colorado Desert called the Pinyons te-wat-em, the cones 
te-wat, and the little almond-like cavities in which the nuts lie, he-push or "eyes" of the te-wat, a very beautiful figure.

The largest, practically pure and extensive forest of one-leaf pines to be found in our southern mountains is on the desert slope of the Santa Rosa range, a locality known as Pinyon Flats, and surely one of the most beautiful and picturesque spots imaginable. The Pinyon is also found on the back ranges of the San Bernardinos and Sierra Madres, forming an extensive but narrow belt all along the Mohave Desert.*

A peculiar weirdness and sadness haunts these sun-drenched open forests of the Pinyon. The hallowed hush of

* It was in this latter region-Cajon Pass that the tree was discovered by Gen. Fremont in 1844 while on his expedition through California.

*The single tree of the Indian Nut Pine found near Pasadena on Mt. Wilson has a history. "On October 10, 1887, Jason and Owen Brown (sons of John Brown of Harper's Ferry fame) built a cairn on this mountain top. They noticed this rare tree, with its roots so much denuded by rain wash and wind that it was ready to die; and they gathered and brought soil in their little dinner pail to pack around its exposed roots, 
the desert is upon them. Here the frequenter of the arid hills loves to dwell, his only visitants being the little wafts of stray, whispering breezes, or now and then a sweet-voiced Desert Sparrow, or playful lizard. Here in the silence and solitude he hears

In the still, sad music of the wild The chords that soothe his heart.

thus saving its life at that time, and hence it has been called the 'Osawatamie pine tree.' Then on August 15, 1893, Dr. Ried found it perishing again from the same causes; Mrs. Reid gathered loose dirt and mulch from between rocks and dragged it on an old barley sack which she had found, to the roots of the tree, while the Doctor laid up a wall of rocks on the lower side to hold the dirt in place; and so its life was saved again. They also broke off some of its dead branches to give the tree a better chance."-History of Pasadena-Ried.

The yellowish, brush-like mistletoe growing on the one-leaf pine is the Arceuthobium divaricatum ENGELM. 


\section{TAmarack OR Lodge-Pole Pine}

Pinus Murrayana MURR.

BARK-I.ight gray, but somewhat pinkish or brownish in the open forest; very thin $(1 / 4$ in) and covered with thin scales.

LFaves-In 2's, 1 to $23 / 4$ inches long; stiff; yellowish green.

ConE-Oblong when closed, globose when open, reddish brown; 1 to $2 \frac{1 / 2}{1}$ inches long; scales with blunt summits, and bearing a minute prickle; seeds winged.

The Murray pine grows only at high altitudes in our southern mountains, being confined to the close vicinity of the highest peaks-San Gorgonio, San Jacinto, San Antonio and Sugar Loaf, where it is the dominant tree, though it is noted as occurring locally at Big Bear Lake (north and south sides at 6700 feet- "A queer misplacement of the species and apparently out of its zone."), and at Bluff Lake. In company with the White Fir, the Tamarack frequents the swampy flower-starred meadows and moist mountain slopes, or with Pinus flexilis climbs the rocky steeps of the highest peaks, running out along the north and east wind swept 


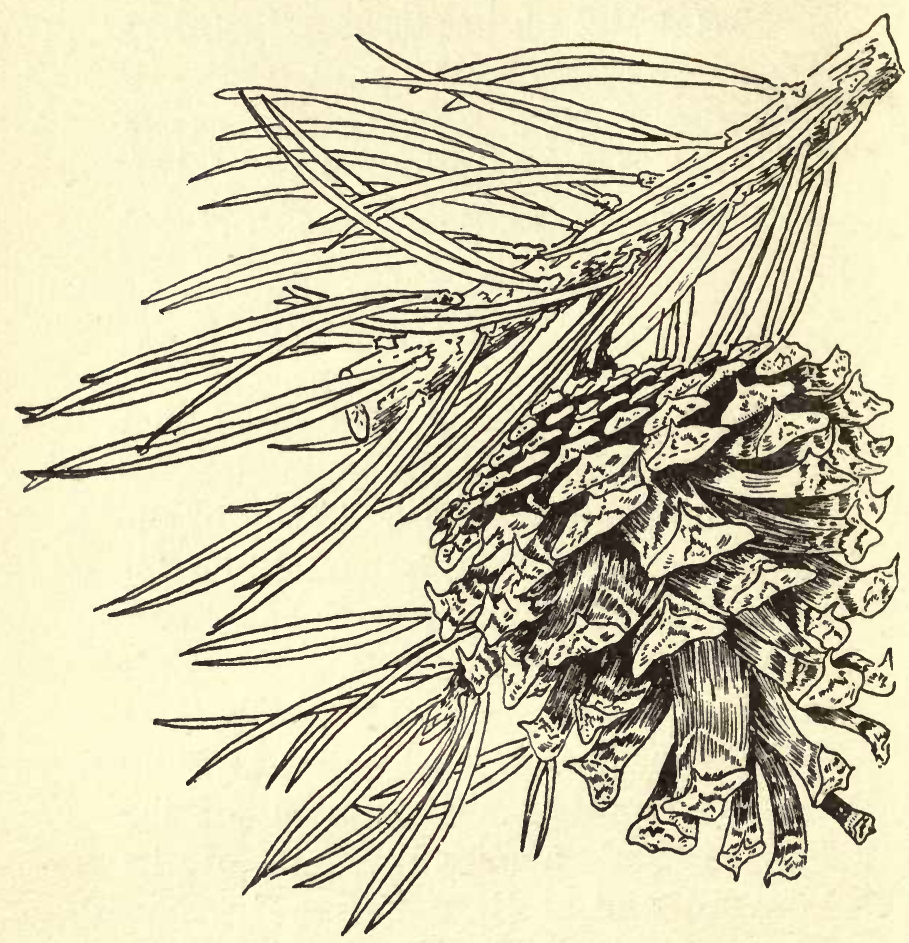

\section{MURRAY PINE}

Cone and branch (natural size).

Perhaps you have wondered how it happens that all the cones of the Tamaracks have such queer, flattened bases. An examination shows that the tiny, flattened and dwarfed basal scales are infertile and hence had never received the stimulation for growth resulting from fertilization of the ovule by the pollen grains. 
ridges. The low, thick and twisted trunks, ice covered half the year, creep slowly for shelter close to the rocky steeps, their gnarled and dwarfed interlaced branches flung like banners away from the wind. Some of these depressed flat-topped heroes are found to be 500 to 800 years old.

With its exceedingly thin bark and its pitch besmeared trunk, the Tamarack is a tree especially susceptible to destruction by fire. Happily the few found in our mountains of Southern California are by their isolation and location at a high altitude, largely freed from this danger. Many are yearly riven by bolts of lightning, however, and the spiral grooves where the electric fire has plowed its way down the trunk, ripping away the bark, are everywhere to be seen. But the sultry weather that brings the lightning also brings drenching showers of rain to these high altitudes and the few fires thus started are soon extinguished. When fires do gain head- 
way in the tamarack forests they run so rapidly from tree to tree that only the resiny bark is singed and the leaves and small branches burned. Though the trees are not consumed the heat is sufficient to kill them and soon the bark and small branches fall away leaving the tall, bare, unburned trunks to bleach like spars in the sun and snow. When finally the roots decay and the anchorage of the spired trunks are gone the glad, strong storm-winds easily blow them down, strewing the ground capriciously with dead crisscrossed logs.

Travellers visiting the headwaters of the Whitewater River (north fork) will find it interesting to note what little direct evidence is now left of the fire which many years ago so disastrously swept through the once heavily forested area on the north side of San Gorgonio Peak. The thousands of erect and prostrate spar-like tamarack trunks which show so gloomily and forlorn on the 
bleak rocky face of the peak have scarcely a fire scar upon them.

The Murray pine is not, like the Ponderosa, a friendly tree. Its very remembrance calls to the mind pictures of chilly bleak days spent under cool damp shades. Storm battered-often, when found in gorges, rock-wounded, bleeding everywhere with resin, and with fallen heroes strewn about in every direction-they are a type of utter bleakness and dejection, especially at eventime after the setting of the sun when the still, lonely coldness of the high altitudes has settled upon the mountain.

The small globular cones are borne in great profusion and their purplish and yellow hues make, when ripe, a most striking effect as that of blossoms. They fall at the end of the second season strewing the ground with a profusion of dainty, prickly burrs which are the delight of every artist.

The name Lodge-pole has been given in reference to the use the plains In- 
dians of the Middle West made of the slender, straight stems in erecting their lodges or dwellings. Tamarack was the name given by the Indians and adopted by the settlers. Murrayana, the specific name, commemorates Mr. John Murray of Edinburgh.

Among the happy June bird residents of these quiet forests are the Sierra hermit thrushes whose bell-like songs fill the air with exalted melody - their first strains arousing "emotions which the regularly falling cadences carry to a perfect close." This mellow flute-like song always carries to me a note of lonesomeness, perhaps because the soul-stirring cadences are so often heard amid the intense stillness of the cool forests.

And do you know the chipmunksthose sputtering bundles of electric energy-who climb the tall timber and scamper with such explosive chipperings along the fallen logs? So full are they of abounding curiosity that never can they hear a squeaking noise with- 
out poking their little round, brown, fuzzy heads out into view. I like to tap the logs gently with a stick and watch them come out of their hiding. Once I counted twenty-one that came up on a single fallen pine, every inch of their bodies quivering with excitement.

But dear little fellows as they are, they cannot keep their paws out of mischief, as the following notes taken from Grinnell's Biota show: "On the upper South Fork of the Santa Ana River, June 28, 1905, I heard," says Mr. Grinnell, "the scolding of a chipmunk accompanied by the excited bill-snapping of a pair of wood pewees. I arrived on the scene in time to see the birds being robbed by a chipmunk; in fact the job was complete, only parts of the egg shells being in evidence when I climbed up. The nest was ten feet from the ground and six feet out towards the end of a horizontal pine branch." 


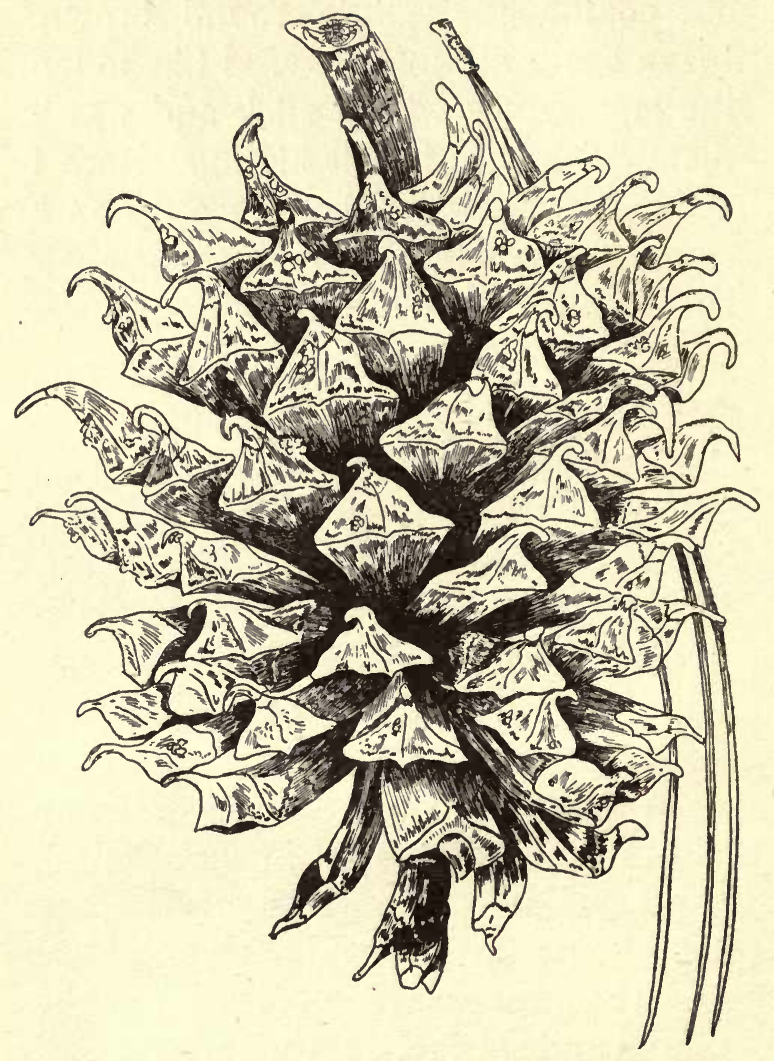

COULTER PINE

Cone and leaf bundle (reduced to one-fourth natural size 


\section{The Coulter Pine}

Pinus Coulteri LAMBert.

BARK--Dark or blackish-brown, broken into wide longitudinal fissures, ridges scaly.

Leaves - 3 in a bundle, $6 \frac{1}{2}$ to 12 inches long, deep bluish or yellowish-green, stiff.

ConE-Extremely heavy, 10 to 14 inches long, spinous processes of scales thick and spurlike. Seeds winged.

This magnificent species of pine was discovered by Dr. Thomas Coulter, the distinguished Irish botanist, on the mountains of Santa Lucia near the Mission of San Antonio. It goes by the name of Big Cone Pine bearing the largest cone of all its family. When mature the cone is as large as a big pineapple and attains a weight of four to eight pounds. Foolish is the man who chooses the shelter of a Coulter pine for a bed site or napping spot. Should some feasting squirrel or a gust of wind set loose one of these big gummy cones and let it come crashing to the ground, the consequences would be serious or perhaps fatal if the cone struck the napper on 
the head. I have personally seen several narrow escapes and when camping I now take care to lay my blankets beyond the borders of a Coulter pine.

This tree is particularly a dweller of dry rocky ridges and slopes; in fact, he seems to be at home nowhere else. Sometimes he wanders far down the boulder-strewn washes and may be the first conifer you see as you come into the mountains. He is then a solitary creature and weathers the heat of the lower altitudes alone. The Coulter pine is rather frequent in the coniferous forests of the San Bernardino, San Jacinto, Cuyamaca, Palomar and Laguna Mountains, but less so in the San Gabriel Range.

The whole tree has a look of openness not noticeable in the pines of higher and more moist locations. Though ordinarily of medium height, 60 feet or so, the main stem may grow, in especially favorable locations, into a much more robust and taller tree. The side 
branches are long and pole-like, the lower ones sweeping far outward and downward, often reaching the ground. The needles are exceptionally long, often attaining a length of twelve inches. They are mostly found on the ends of the thick stems grouped in thick broom-like clusters.

Since the cones are so heavy, they seldom reach the ground in a whole condition. As you find them on the ground they are often much the worse for their fall. On the cone-bearing stalks are generally found a few persistent scales which parted from the cone as it broke away and fell. Young trees 20 and 30 years old bear cones generally in three-year cycles. The cones mature by August of the second season. The Anthony gray squirrels are very fond of the big fat nuts inside and many a cone is harvested long before mature by these little workmen of the woods. It is very strange but the squirrel never gets his paws gummed up 
when gathering his nuts although the cones are about the stickiest things imaginable. "The squirrel," says Thoreau, "has the key to this conical and spiny chest of compartments. If you would be convinced how differently armed the squirrel is naturally for dealing with pitch-pine cones, just try to get one open with your teeth. He who extracts seeds from a single cone with the aid of a knife will be constrained to confess that the squirrel earns his dinner.

"The plucking and stripping of a pine cone is a business he and his family understand perfectly. He does not prick his fingers, nor pitch his whiskers, nor gnaw the solid cone any more than he needs to. . . . He holds in his hands a solid embossed cone so hard it almost rings to the touch of his teeth. He knows better than to cut off the top and work his way downward, or to gnaw into the side for three-quarters of an inch in the face of so many armed [spiny] shields. $\mathrm{He}$ whirls it bottom 
upward in a twinkling, and then proceeds to cut through the thin and tender bases of the scales, and each stroke tells, laying bare at once a couple of seeds. Thus he strips it as easily as if scales were chaff, and so rapidly, twirling it as he advances, that you cannot tell how he does it till you drive him off and inspect his finished work."

A yellowish, brittle-stemmed mistletoe (Arceuthobium occidentale ENGELM) lives on the Coulter pine and White Fir. I shall never forget my first experience with it. I plucked a spray in order to sketch it, and as I did so, a jet of gluey fluid hit me on the eye. Then another spirt came on the cheek. For a moment I was puzzled to know what it meant. Then I discovered that the shiny, white berries were discharging their seeds at me-not with evil intentions, however; it was the mistletoe's method of seed dispersal. The viscid fluid within the berry and surrounding the seed is under such intense internal 
pressure that when the ripe berry is jarred from its hold an explosion takes place, shooting the seed with its mucilaginous pulp out into the air. Records are given of seeds being thus shot to a distance of 13 feet, and wherever they land they stick. Put a sticky seed on your skin or clothes and see how difficult it is to rub off.

Birds feasting on these berries get their bills covered with the gummy seeds and in trying to clean them off by wiping them on the bark of trees, distribute the seeds. The viscid pulp soon hardens affording a protection to the seed. 


\section{Digger OR GRAY PINE}

Pinus sabiniana* Doug.

BARK-Grayish brown, roughly furrowed and ridged.

LEAVES- 3 in a bundle, $81 \frac{1}{2}$ to 12 inches long, sparse and drooping, grayish green.

ConE- $-6 \frac{1}{2}$ to $10 \frac{1}{2}$ inches long, chestnut brown. Scale tips terminating in stout, straight or hooked spurs each about an inch long. When the cones fall they break through near the base like the Coulter and Ponderosa cones, leaving the basal portion attached to the limb ("broken cone" type of pine).

Another nut pine, the Gray or Digger Pine, found commonly on the slopes of the Tehachapi Pass and northward, extends in scattered groups southward to the Mt. Pinos region in Ventura County and the northern portions of Los Angeles County. The conspicuous features of the tree are, the relatively scanty bluish-gray foliage, the large heavy cones with their chestnut-brown incurved scale-tips, the usual elongated V-shaped fork and leaning trunk. Comparitively early in the life of the tree the main stem-axis ceases its growth and

* Joseph Sabine, after whom the tree was named by David Douglas, was Secretary of the London Horticultural Society. 
MOU NTAIN TREES

two lateral branches below begin to grow out and take its place, giving the t $r$ e e its unconventional, broom-like forked form.

Says Jepson: "It makes an unsatisfactory lumber when sawn, on account of its faculty for warping. The woodsmen say with humorous exaggeration, 'Boards from the mill stacked outside to season will walk off the lot over night.' " 


\section{Western Yellow Pine}

Pinus ponderosa LAWson.

BARK-Yellowish-brown to russet-red, broken up in old trees into large smooth or scaly plates, scales concave and easily peeled. Younger trees with dark red-brown or almost black bark, finely fissured.

LEAvEs-In 3's, 43/4 to 11 inches long, deep yellowish green, remaining on tree about three years.

Cones-Russet-brown, egg-shaped, $23 \%$ to 5 inches long, scales armed with short prickle, seeds winged. Cones mature in August at end of second season.

This is the most widely distributed of any of our California pines, in fact, no tree in North America can boast of a wider distribution. From the mountains of Northern Mexico to Southern British Columbia it is everywhere at home and if we include its variety $P$. ponderosa scopulorum of the Rockies we may say that it occurs in every state west of the Great Plains.

Speaking of this tree, Sargent says: "It surpasses all its race in the majesty of its splendor and vitality." Old giants often rival in beauty the magnificent sugar pines, their bizarre forms standing 


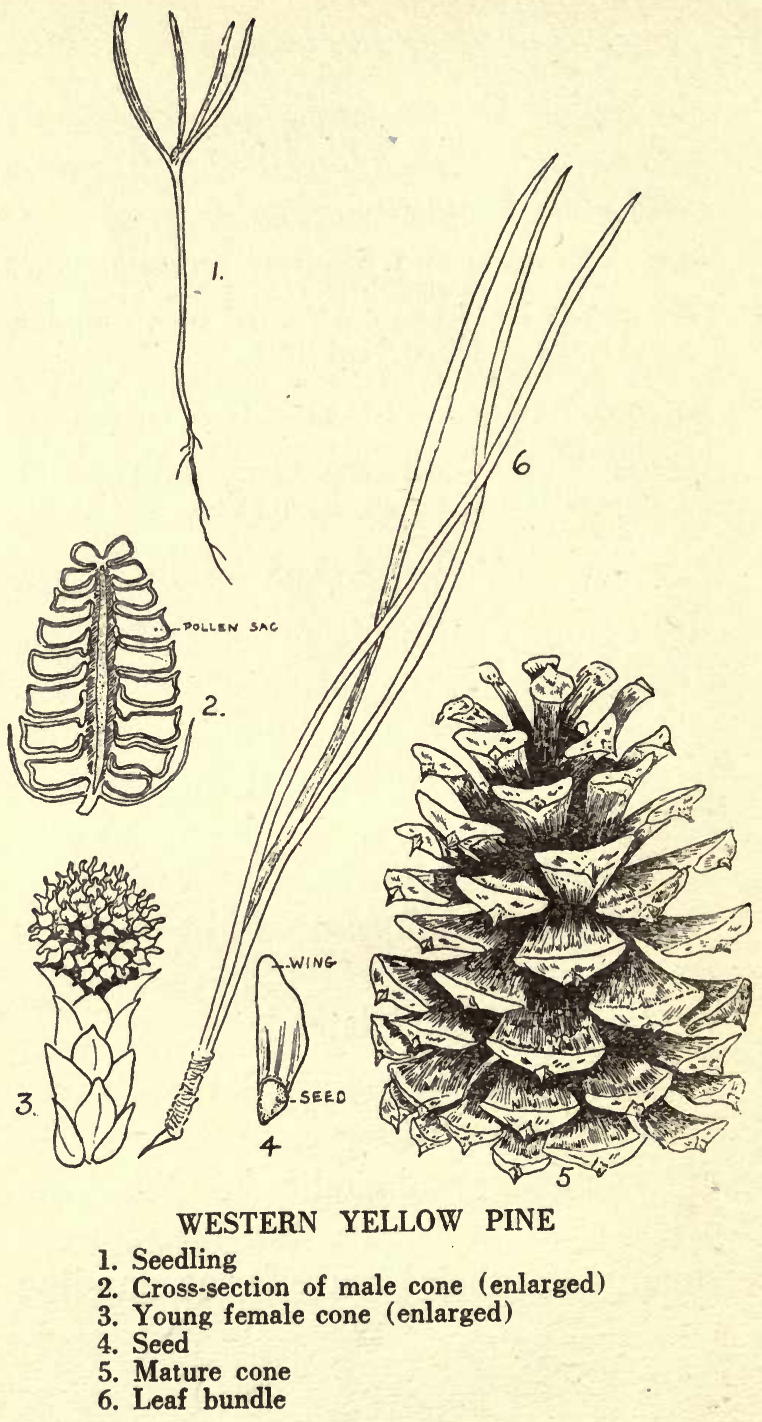


out boldly and towering high above the silent sea of pines about them. The specific name ponderosa was suggested by David Douglas in allusion to its imposing stature.

In our mountains of Southern California it is by far the most prevalent conifer and composes the great bulk of our forest, forming magnificent areas of wooded country especially in the San Bernardino and San Jacinto Mountains. Though ordinarily a dweller of the slopes with an elevation of from 4000 to 7000 feet, on the south side of Mount San Jacinto a few trees have climbed the slopes to an elevation of 9800 feet, one of the highest recorded stations for this pine. Grinnell notes its occurrence at 9000 feet near Sugar Loaf Peak and Dry Lake.

The dry powdered resin of the yellow pines is used as a dusting powder for sores. Settlers mix the resin with corn meal and apply it as a poultice to produce counter-irritation. (Schneider.) 
Look on the bark of the yellow pines for the ingeniously made cupboards of acorns fashioned and filled with food by the California Woodpecker, El Carpintero, as the Mexicans love to call him. Perhaps some day you may hear and watch him tinkering around, gouging out holes, or fitting acorns into them. Whole trees are often covered with his work and tens of thousands of snugglyfitting acorns await the day of his winter hunger. Only the sweet-tasting acorns are chosen and these he stores, not so much for the grubs that may grow within them, as for the sweet nut meats which he likes to eat. High, dry and embosomed in the bark of the tree, the Carpenter's pantry provides him a dinner when the food of other birds is hidden in the snow. The squirrels are not the most honest creatures and the woodpecker seems to know it. Were the acorns stored otherwise than they are or fitted in less ingeniously he knows their fate at the nimble hands of the squirrel. 
Mrs. Eliza Donner Houghton, one of the few remaining survivors of the ill-fated Donner party, tells me that, as a little child, she noticed that the holes were always bored at a downward angle so that it was impossible for the squirrels to get a straight pull on the nuts, the acorn's points always turning up when an attempt was made at extraction, thus lodging the nuts in tighter than ever. Question-Does the wood-pecker know his business?

Particularly noticeable for beauty is the trunk of the Ponderosa with its great plates of salmon-red bark. These noble, smooth, richly-hued shafts stand like colonnades and pillars in the great temple of the out-of-doors. Happy and fortunate is that man who worships in quietness in this cathedral of God's design with its sun-splashed and carpeted aisles of rare scented needles.

Would you know peace, would you learn gentleness, do you long for rest? It is here for you in these quiet woods. 
The chicadees will sing you their dear little song, and juncos and towhees, scarce knowing the sight of man, will hop down by your side and peaceably give you their merry chirp as they hunt among the pine needles for their morning meal. Gold and lavender flowers, bordering the meadows, will nod to you as they sway in balmy mountain breezes and speak of God's love and graciousness. They will not chide you for your short-coming; they know not how to give looks of reproach; they can only point to the way of gladness of heart. 


\section{Jeffrey Pine}

Pinus ponderosa var. jeffreyi vaSEY.

Bark-Redder than in Ponderosa, running almost into black and broken into very much smaller plates and ridges.

LeAves-5 to $9 \frac{1}{2}$ inches long, hanging on the tree from 5 to 8 years; appearance similar to Ponderosa.

Cone-Similar to Ponderosa, except that they are much larger (5 to 11 inches long), and somewhat rounder and denser.

This is but a variety of the Pinus ponderosa and hence has many characteristics of the latter tree. There is such a gradual gradation from the pure Ponderosa type to the pure Jeffrey variety that often it is difficult to give a rigid classification to many intermediate trees. The best field marks are the finely cut wine color bark streaked with black (hence sometimes called Black Pine), and the larger cones. Generally the pure stands of Jeffreys are found at higher elevations than the Ponder-

John Jeffrey-a Scotch gardener who collected both plants and seeds in Oregon and northern California. (1852.53) 
osas. There are those who claim they can distinguish these trees by tasting the sap in the needles.

Did you ever stop to think of the forces at work in the trunk and leaves of one of these forest monarchs: what energies are required to pump the sap to the pinnacles of the high crowns, what chemical agencies are ever at work in the manufacture of food, what marvelous adaptations are present for the conservation of moisture? The internal pressure in cells of trees is so intense as to seem almost incredible. Weiler, when experimenting with Scotch fir, found that in the young wood cells the pressure was 240 pounds to the square inch. Dixon found in the cells of certain leaves a pressure of from 150 to 450 pounds to the square inch. As said by G. Scott Elliot, "no locomotive engine has cylinders strong enough to resist such internal pressure as this."

Plants have satisfactorily solved a problem in support the solution of 
which engineers have never found. A chimney 50 feet high must have a diameter at base of at least three feet, but a tree with the same diameter will often run upwards over a hundred and fifty feet, and the tree has leaves and branches to support besides its own trunk. It is said that a rye plant will support a stem that is $\mathbf{5 0 0}$ times its diameter.

The giant pines and other forest trees growing in rich, humid soil are not ashamed to accept, in their effort to get a living from the soil, the assistance of certain small fungous plants known as mycorhizas. These form peculiar feltlike sheaths about the roots and enter into closest relations with the root surfaces contributing to the tree nutrient materials, especially needed mineral constituents which could not be otherwise secured by the roots. It is possible that in the case of older roots which have lost most of their root hairs, the fungous filaments considerably in- 
crease their absorptive area and continue indefinitely their ability to absorb water.

In exchange for this valuable service, the fungus, acting as a parasite, exacts by means of its delicate, branching filaments which penetrate the root cells of the host, a toll of food for itself. Such a mutual and beneficial partnership is known as a symbiosis.

There is a beetle, a portion of whose life history is intimately bound up with the dying days of many of the forest trees. This is the big Pine Borer, Prionus californicus, who is responsible for the big holes and tunnels in the dead and fallen logs of the pines and firs. The adult forms are familiar sights at night about mountain resorts. They fly into open doors and windows, annoucing their arrival by a great clattering of wings. The curious who try to pick them up find that the big, brown-bodied, long-horned creatures are possessed of powerful, vicious, incurved mandibles 
capable of inflicting painful wounds. The rasping noise made when they are disturbed is made by rubbing the tibial portion of the second pair of legs against the outer edge of the wing covers. During the late summer the female lays, by my actual count, from 200 to 250 eggs, each about as large as a small, narrow, rice kernel, in the crevices of the bark of some dying tree. These hatch into small larvae with powerful sickleshaped jaws capable of boring through the wood like an auger. Often if you will put your ear up to the dying tree you can hear the crunching and grinding of the jaws. The larvae grow larger and larger eating the wood as they go, leaving the tunnels behind them packed with woody chips. At a certain stage of growth a cell is partitioned off with chips just beneath the bark and there the borers lie dormant for many months while those mysterious changes take place which transform the soft-bodied grubs into mature adults. 


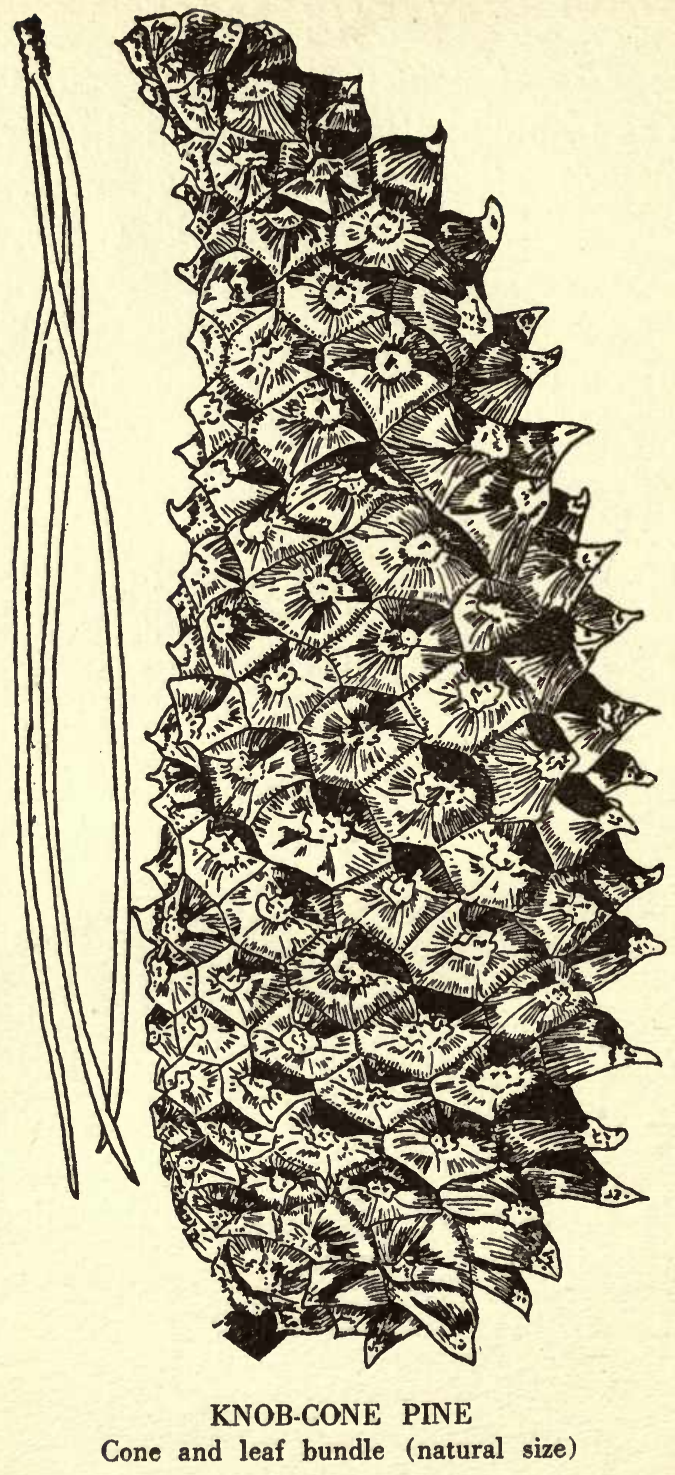




\section{Knob-Cone Pine}

Pinus attenuata LEMMON.

BARK-Thin, dull brown and slightly fissured and ridged, ridges with large loose scales.

LEAVES - In 3's, slender and often twisted, 3 to 5 inches long, yellowish- or grayish-green, sparse, persisting on stem 4 to 5 years.

Cone--Buff colored, strongly flexed backwards, 3 to 6 inches long.

The only known natural occurrence of this pine in Southern California is on the arid southern face of the San Bernardino Mountains in the vicinity of the great $\mathrm{R}$ cleared from the chaparral by the students of the University of Redlands, and near City Creek. The trees are dwarfish, ranging in height from 5 to 15 feet, with long sweeping branches curving outward from the main stem. The few trees found on the San Gabriel Mountains back of Pasadena were planted by the late T. P. Lukens as an experiment in reforestation. A most important botanical discovery was made by excavators at work in the $\mathrm{La}$ Brea pits when they found cones of the Knob- 
cone pine embedded in the tar with prehistoric elephants, saber-toothed tigers and giant sloths, showing that this tree, in prehistoric times, grew much nearer the coast.

When the tree reaches an age of seven or eight years it begins to bear cones. These hang in close groups rigidly attached to the main stem and after mature adhere indefinitely. Often as the tree increases in size these persistent, narrow-based cones become imbedded in the bark. In the office of the Forest Supervisor, Los Angeles, is a branch of a tree less than nine inches long with 28 partially buried cones upon it. Some trees, according to Sudworth, show that they have retained their cones nearly fifty years. The seeds of these, on being opened, were found to be still alive, showing a remarkable vitality over the deciduous-coned pines whose seeds seldom retain their power of germination more than two seasons. The cones only open when the tree dies a natural death 
or is fire-killed. The seeds held in store during the whole life-period of the tree are then lavishly sown and an abundant growth of seedlings comes up. Such is Nature's forethought in preserving the forest cover. 


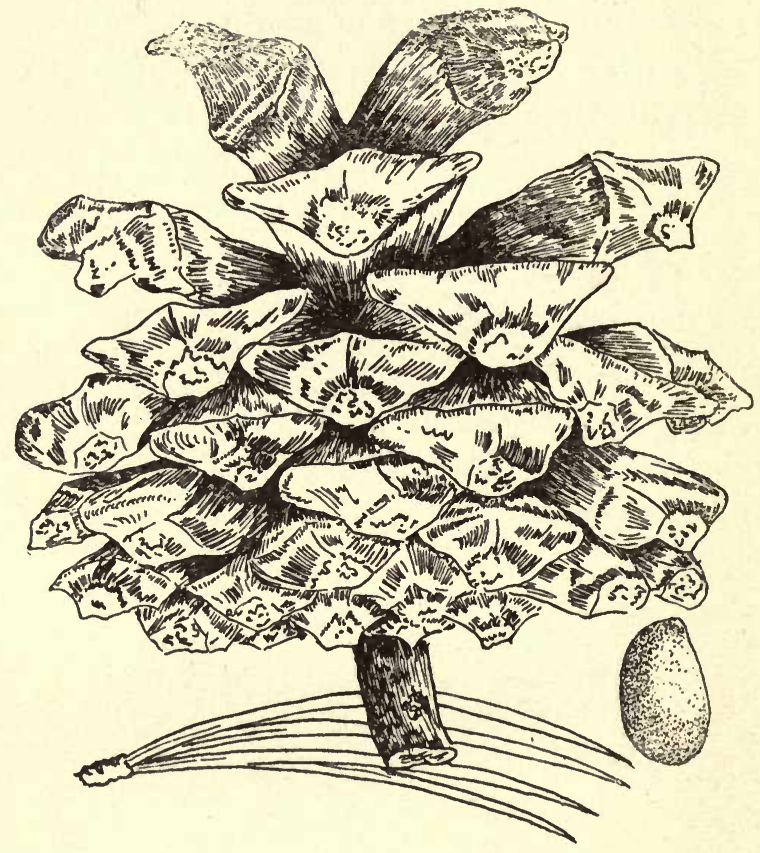

FOUR-LEAF OR PARRY PINE

Cone, leaf bundle and nut 


\section{FOUR-LEAF OR PARRY PINE}

Pinus quadrifolia SUDWORTH.

BARK-Thin, shallowly fissured into flat ridges, scales few or none, dark reddish-brown.

LEAVES-In fascicles of 4 , sometimes 3 to $5,1 \frac{1}{4}$ to $13 / 4$ inches long, pale green, somewhat scattered on the twigs, persisting from 3 to 5 years.

Cone-Brown and shining, $1 \frac{1}{2}$ to 2 inches long, scales without spines.

Probably this is the least frequently seen and known of all our pines; first, because it is so often confused with the single-leaf pinyon which it in many ways so closely resembles; and second, because of the remoteness of the localities where it grows. The northern limitof this hermit tree is Cahuilla Valley and the very southernmost portions of the San Jacinto Mountains, where a single tree stands close to the road on the Nigger Jim Grade between Kenworthy and Cahuilla. It also occurs sparingly in desolate Coyote Canyon, on the bleak sides of Toro Mountain in the Santa Rosa Range, and on south into Lower California. 


\section{MOUNTAIN TREES}

As suggested by Mr. J. G. Lemmon, this and the other nut pines represent the "provident, liberal element" in the pine family. They bend their bountiful stores of nuts on low-hanging branches and grow where no other food tree could exist. The scales of the cones are unarmed with prickles and bear the largest, most nutritious and delicious seeds of any of the pines. 


\section{Limber Pine}

Pinus flexilis James.

BARK-Thin, narrowly fissured into dark brown blocks, scales when falling expose a reddish inner layer; on younger stems it is thinner and almost white.

LEAVES-In 5's, dark green, stout and stiff, sharppointed, crowded at ends of branches, persisting 5 to 8 years.

Cone-Long, oval, 3 to 5 inches long, thickened ends of scales terminating in a stout, incurved tip, wing of seed very narrow.

In companionship with the Murray Pine, Pinus flexilis climbs the dry, rocky and exposed slopes of the higher ranges. * In the rocky, talus-cluttered gulches near the summits of San Gorgonio and San Jacinto Peaks, where some protection is offered from the high winds, the trees grow quite straight and tall. But the most interesting and beautiful forms are those of the exposed ridges, where gnarled, twisted and pros-

* It seems probable that the Limber pine whose home is in the Rocky Mountains has entered Southern California by way of the desert ranges, the highest peaks of which served as stepping stones between the Rocky Mountains and the higher ranges of middle and Southern California.-HALL. Found also on Santa Rosa Peak, 25 miles southeast of San Jacinto Peak. 


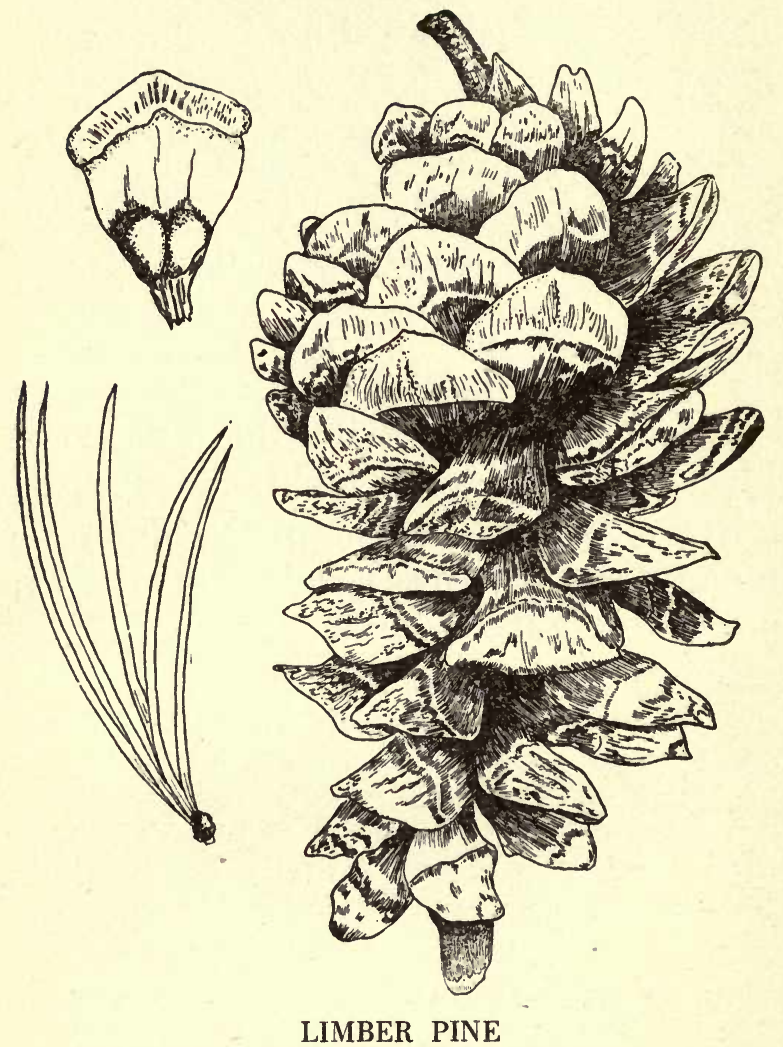

Leaf bundle, cone and single scale with nuts exposed 
trate their thick and ancient trunks seek shelter from the fury of the winds. On the leeward side beneath the low, stormbeaten, creeping trunks are often found delightful low nooks just about large enough for a cozy bed. Since a soft bed of needles is generally there, too, these hospitable shelters are always welcomed by the traveller when spending the night on the high wind-swept peaks.

Familiar to the frequenter of the high mountain trails which lead among these forests is the harsh, raucous and discordant cry of the Clarke Nut-cracker. No matter how often you enter these domains you always find this saucy bird ready to entertain you. On the edge of the Tamarack forest he meets you, to escort you through his haunts. Ever on the move he keeps just ahead at a safe distance, alighting invariably in some dry tree where he can watch you. If you stop for a few minutes he may fly to some green, cone-laden tree and still 
on the watch begin to feed on the seed of the pines. "These noisy seed-hunters," says Ridgeway, "use their formidable claws to enable them to hang onto the pine-cones while they are extracting the seed which they are obliged to get out from under scaly coverings. For this nature has given them feet and claws that serve the purpose of hands, and a powerful bill like a small crowbar. The cone must be steadied when they pry it open, or it would snap and fall. One foot clasps it, and the powerful claws hold it firmly. The other foot, encircling a branch, supports the bird in every position, the long grasping claws being equal to any emergency. The cone is thus fixed and the seeds are forced out from under the scales." 


\section{The Sugar PINE}

Pinus lambertiana DOUGL.

BARK-Brown or reddish-brown often with a purple tinge, fissured into long finely broken plates. Bark of young trees, smooth and grayish.

LEAvES - 5 in cluster, dark green, sharp pointed, and from 3 to 4 inches long.

Cone-Large, from 12 to 20 inches long, pendulous, light brown when mature, very resinous. Seeds shed in autumn of second season. The cone persists to the third season-scales without knobs or prickles.

Ever since its discovery by David Douglas, writers have vied with each other in their attempt to adequately describe the majestic sugar pine. It is the forest's choicest child upon whom she has lavished consummate grace of branch, leaf and cone. The upper branches are widely spreading and terminate in tapering upturned points, except when weighted with clusters of pendent cones. The lower branches are inclined to droop like those of the Norway spruce-the whole giving the tree a most picturesque aspect. The fine fingered needles when caressed by 


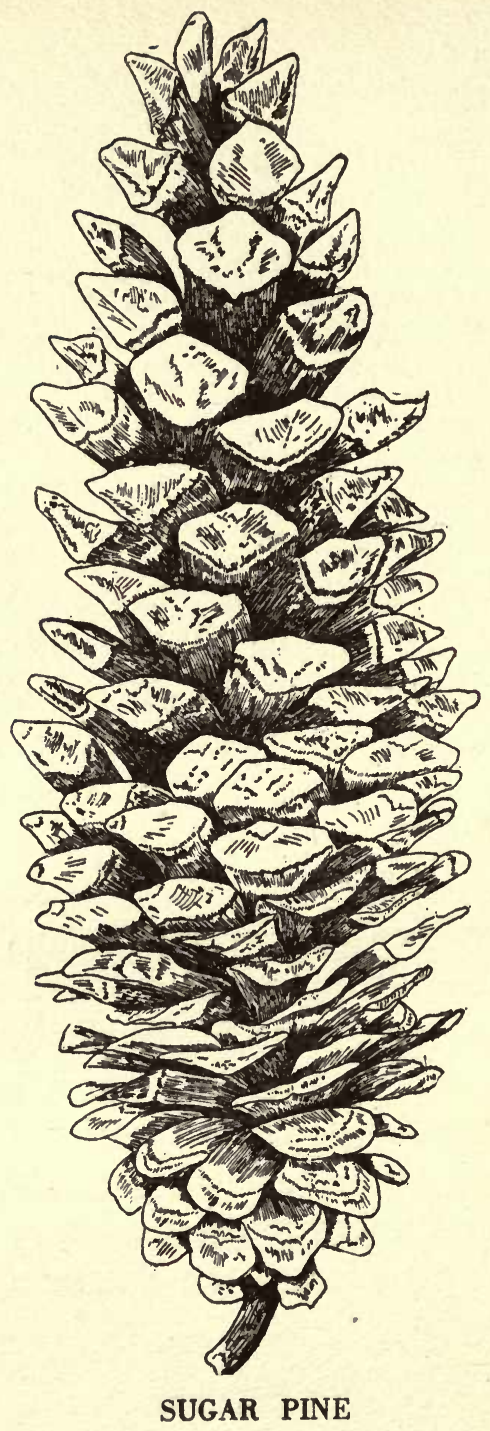


mountain breezes produce forest melodies unapproachable in tone sweetness. The cone of no other conifer is so beautiful in its tapering symmetry.

Have you ever noticed at the base of a bundle of pine needles, the sheath of paper-like wrappings which appear a great deal like many little gray threads wound about the leaves to hold them in a bundle? These little wrappings are the scales of the buds from which the leaf bundle springs. When the needles are young, the bundle, enclosed in its sheath of scales, looks like a pin feather. All the soft pines, of which the sugar pine is an example, shed these bud sheaths early, while the pitch pines retain them so that they fall with the leaf bundles.

Every bundle of pine needles is really a very short branch with the leaves set so closely together that they form a cluster. At the very base of the bundle, beneath it, and on the main stem of the new branches of spring are the primary 
or proper leaves of the shoot, which look not at all like foliage, but rather like delicate scales. These soon fall away. Another kind of leaf of pines is the simple juvenile leaf of the sapling. Scientifically speaking even the scales of the cones are leaves, modified for the special work of seed production. So then, we may say that a pine tree has four kinds of leaves-juvenile, primary, foliage and sporophyll.

The beauty of the shafted trunks and pole-like limbs of the sugar pines is further enhanced by the finely branched, brilliant yellowish-green tufts of Evernia vulpina or Wolf Lichen, the most beautiful and conspicuous representative of our lichen flora. It generally grows on the shaded side of the tree and goes under the common name of moss, though not a plant of that order at all, but a dual organism composed of an alga and fungus growing in symbiotic union. This lichen is widely distributed and was used by the Indians as a basis for a 
dye. It grows also on yellow-pine, white fir and manzanita. The blackishbrown concave or flat disks with their beautiful fimbriated crowns of green are the spore or fruiting cups. Though fixed on the bark of the tree by a basal plate the lichen is not parasitic but derives its nourishment from the atmosphere and the rain which falls upon it.

The splitting open or turning over of a damp, decaying log may reveal to you almost any early summer day numbers of those curious half plant, half animallike creatures known as slime molds or myxomycetes. Because of their interest I beg you to look for them. They are slimy, gelatinous-like masses resembling white of egg or jelly and are of different colors and forms, and varying in size from that of a pin head to a man's hand. By thrusting out their jelly-like fingers in streaming motions they manage to creep about in cracks of decaying wood or on damp leaves, feeding as they go. As the whole homogeneous mass 
moves forward decaying particles or other foods are engulfed and digested and the worthless undigested residue left behind. Though possessing little apparent organization, these queer amoeba-like combinations of plants and animals are capable of responding to stimuli and avoid with a wonderful nicety any strong light. As the slimy bodies approach the final stage of their lives they change their taste for darkness and moisture and seek light and dryness. Coming to rest on the outside of some $\log$ they organize themselves into numerous fructifications or spore sacs of various forms. Thus this creature which has started its life like an animal has ended its career by producing spores like a plant. 


\section{The Big Cone Spruce}

Pseudotsuga macrocarpa TORR.

This is ordinarily the first cone bearing tree you find when climbing the mountain canyons. It is peculiar to Southern California, being found nowhere north of Santa Barbara County. While it particularly seeks the shades of the deep canyons, where it huddles close to the streams and grows very straight and tall, it also ventures out in places high up on the steep north slopes between the chaparral and yellow pine belt where it forms lone and picturesque groups.

Its worst enemies are the frequent fires which sweep through the chaparral. It is a slow seeder and once firedestroyed, it is a long time before the area is reforested. One of the saddest sights the tree lover meets as he ascends the lower slopes and canyons are the blackened forms of the spruces silhou- 


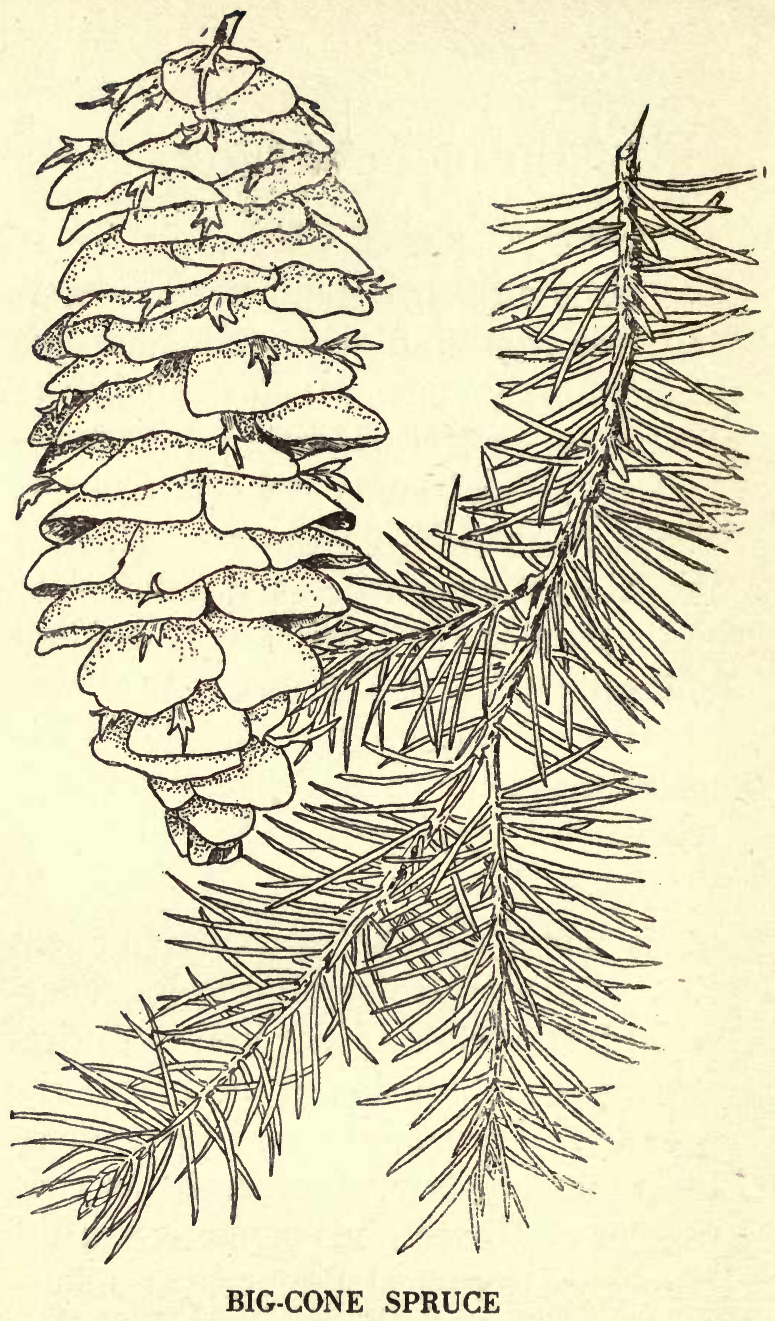


etted against the skies, marking the devastation of recent fires.

A noticeable feature of the cones and one which makes this tree easily distinguishable from the other conifers, is the presence of the rather thick fringe-like bracts protruding beyond the scales. The cones mature the first year but remain hanging on the trees after the seeds have fallen out. Pseudotsuga is derived from the Greek pseudo, false, and the Japanese tsuga, hemlock; macrocarpa means large fruit. 


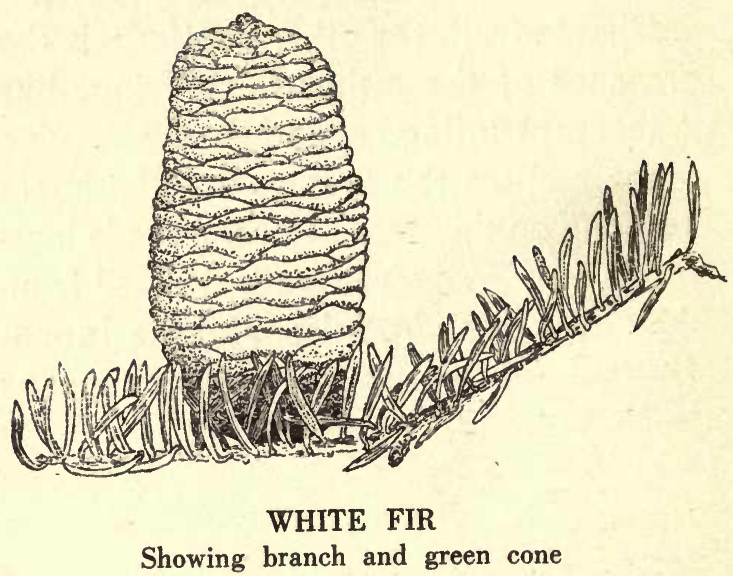




\section{WHITE FIR}

Abies concolor PARRY.

Large trees with old bark, rough, gray and furrowed, and stained with rich ancient browns-how goodly is their company! They are the lovable old patriarchs who have words of wood wisdom and of history for all who will to know the story of their lives. The days of their sojourn here have been many. Record has been kept by them in their wounds and scars of the struggles with the furor of storms through a hundred seasons; in the rings of their trunks is found the story of wet season and drought; they know the ways of their friends, the birds, and offer from generation to generation without restrictions, homes to the feathered flocks.

Helped by the squirrels, the winds and birds, the seeds from season to season have been sown, and now about their borders have sprung up little groups of dainty saplings and older tree chil- 
dren to continue the beneficent work of conserving the forest cover. The youngest of these are fresh with the newness of life, symmetrical, prim and beautiful in their dress of silver, bluish-green foliage, but the older ones after reaching the half-century mark begin to lack this convention of form and are becoming unsymmetrical and shaggy like their hoary forebears.

Some of the prettiest of the firs are those with spike tops. Such trees have either been lightning struck, injured by a Tussock moth, or have nourished a mistletoe which has circled and killed the branches. I have often noticed how the birds enjoy these naked spired branches as look-outs. I remember an old hawk who spent about half his time in such a spike-topped fir.

Trees growing in full light have heavy, silver-green, plumy branches while those deep set in the forest shade have the leaves arranged sparsely in thin flat sprays much like the redwoods. 
Often so great is this difference, caused by environment, that the unwary think they have found two different trees. If you will closely examine the leaves of the fir you will notice that they are striped beneath with two long stripes of white breathing pores, giving the foliage a "glistening sheen of silver"-hence the oft-given name-SILVER FIR.

The cones of the firs are never found by looking for them on the ground. Unlike the pine cones they are borne erect near the top of the tree. When ripe each of the paper-like scales falls away separately, leaving the thin, pencil-like axes of the cones standing like candles on a Christmas tree.

The conspicuous, pendulous, filamentose, grayish green "beard moss" found so plentifully on the White Fir, Western Yellow Pine and occasionally on Kellog Oaks in Grass Valley and near Little Bear Lake is Usnea ceratina, an apparently rare lichen. 


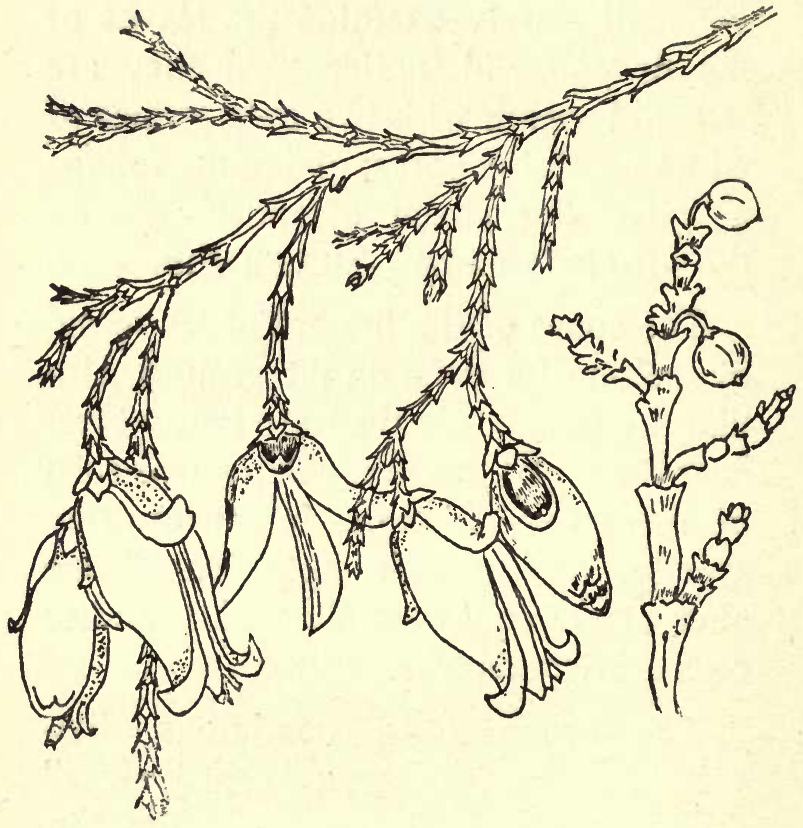

INCENSE CEDAR

Showing cones and leaf arrangement. To the right is shown one of the mistletoes growing on the Coulter Pine 


\section{INCENSE CEDAR}

Libocedrus decurrens TORR.

This beautiful conifer, discovered by Fremont in 1846 on the upper waters of the Sacramento River, has received the name of Incense Cedar because of the aromatic resin which perfumes its bark and leaves. The leaves are short, flat scales arranged in broad sprays of intensely rich green. They are in whorls of four but so closely adherent to the stem that they are not easily recognized as true leaves. Only the sharp ends of the outer leaves are free. The inner ones are much compressed and almost completely covered by the outer lateral leaves so that the stem appears jointed. The specific name decurrens refers to the fact that the leaves are prolonged on the stem beneath the point of their apparent insertion.

The bark of the older trees is of a rich cinnamon-red color, thin and scaly, and LIBAS, a drop, of resin and cEDrus, Cedar. 
when scaled comes off in long pithy shreds. It was often used by the Indians in the construction of houses and for tepees in which they sought shelter while gathering the year's acorn crops in late October and early November. The remains of several of these tepees may yet be seen in the Palomar Mountains of San Diego County.

Though ordinarily unnoticed the Incense cedar has its crop of cones just like the pines, though the cone is very much smaller, consisting of but six scales. Only the two largest of these bear seeds and are noticeable. The cones are of most graceful outline and present a most artistic effect when seen in cluster. If you do not find them on every tree do not be surprised. Remember that these mountain trees have their "off years" like fruit trees in the valleys, when the frosts come just at blossoming time and kill the promised fruit. It may be that you will find few cones or none at all on the conifers of certain localities 
for a number of years and then after that will come a year or years of abundance when every branch is hanging low under its weight of pendent cones.

The flowers appear late in Januaryvery early in the season for a tree of such altitudes. Male and female are borne on the same branch, but on different twigs or on different trees. Many people do not even suspect that a pine tree or a cedar has a blossom, but once they see the male blossoms of the cedar, yellow with their loads of pollen and so thick that the tree is one mass of gold, they will never again doubt their existence. It may here be remarked that it is always the female blossom which develops into the cone.

The Incense cedar requires more moisture than the Yellow pine and is therefore restricted to the large valleys and vicinity of streams. It can be propagated from cuttings taken from the branches of one year's growth, and is kindly adaptable to home gardens. 
In cutting into old or decaying cedar, oblong pockets filled with a brown charcoal-like mass are often seen. This is the work of a fungus (Polyporus amarus) whose mycelial threads penetrate everywhere through the heartwood, weakening the tree and destroying its value. The fruiting bodies, produced annually, issue from knot holes and are greedily devoured by insects and squirrels who relish the soft, mushy, knobshaped masses of spores.

The Incense cedar is the host of a certain tree thief, a leafless mistletoe (Phoradendron juniperus librocedri), the luxuriant growths of which are often conspicuous on older trees. Being a light-seeker this mistletoe is most often found high in the tree. It is long-lived and has been known to live more than 220 years. Longitudinal rows of small holes in the wood are caused by woodpeckers or by the roots of the Phoradendron. 


\section{WESTERN JUNIPER}

Juniperus uccidentalis ноок.

The dominant notes of the burly, scant-foliaged juniper are its sturdiness, dignity and repose. The thick-set, stocky trunks covered by the bright, cinnamon-red bark appear immobile as stone. "They are never," says John Muir, "blown down so long as they continue in health. Their stiff, crooked roots grip the storm-beaten ledges like eagle claws, while their lithe, cord-like branches bend round compliantly, offering but slight holds for winds, however violent."

The Western Juniper thrives best at high elevations and is found in an almost pure forest of considerable extent to the north of Bear Lake and into Holcomb Valley. It is common around the lake itself, also on Gold Mountain and Sugar Loaf Peak. A few trees occur locally on Mount San Antonio. 


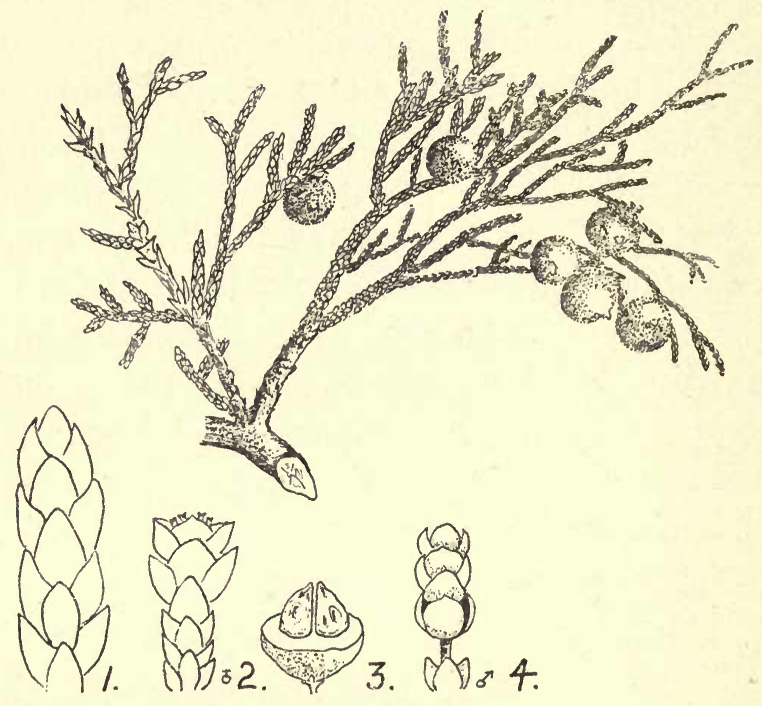

MOUNTAIN JUNIPER

End of stem

2. Female blossom $(x)$

3. Fruit cut to show seeds

4. Male blossom (x) 
The fruit, in appearance like a berry, is a true cone. Unlike the cones of the other conifers the few cone scales of the junipers are fleshy and juicy and ripen at the end of the second season into a sweetish, blue-black fruit, containing two or three seeds. These globose "berries" are gathered and eaten by the Indians. Birds and wild animals also relish them.

The Indians used the pitch of the juniper to fasten feathers to arrow shafts and rubbed it into the shafts to make them stronger and elastic (U. S. Disp.). 


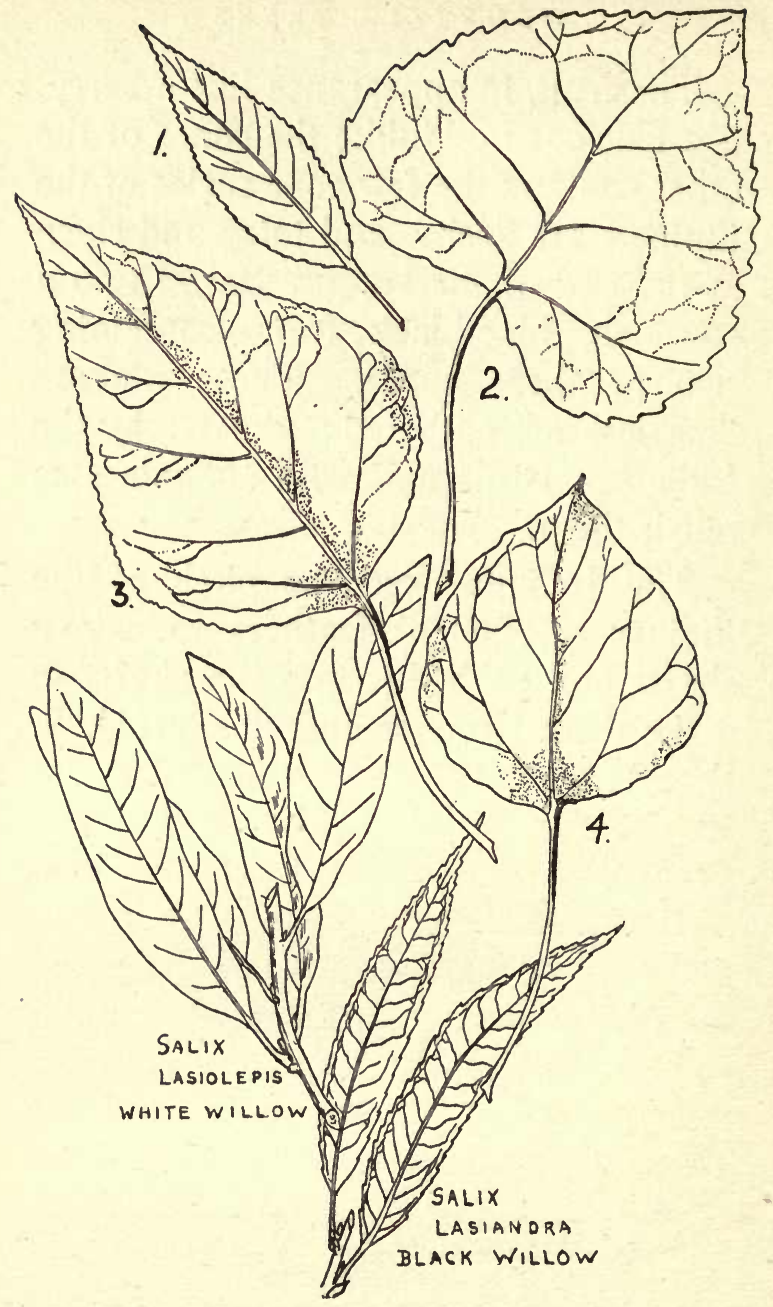

THE COTTONWOODS AND WILLOWS

1. Narrow-leaved cottonwood

2. Fremont cottonwood

3. Black cottonwood

4. Quaking Aspen 


\section{COTTONWOODS AND ASPENS}

The Cottonwoods and Aspens are all cheerful, sun-loving trees found in the vicinity of streams or out-croppings of dampness. Their ovate or deltoid leaves, fingered and carressed by warm, ascending breezes, and splashed with sunshine, continually flash greetings to us. Like pendent, silver spangles, they are ever in motion, exchanging confidences among themselves or clapping hands and clattering loudly as their surfaces strike more harshly under the influence of stronger wind gusts.

The cottonwood, found in the open valleys along the San Luis Rey, San Jacinto and Mohave rivers, with bright, green, triangular, yellowish-green leaves, whitish, much furrowed bark, wide-spreading branches and broad crowns, is the Fremont Cottonwood (Populus fremontii). It ascends some

Populus is the Latin name of these trees, and is from Populus, $\mathrm{L}$, the people, from the number and continual motion of its leaves like a populace. 
distance along the mountain streams, especially on the desert slopes, where it endures with remarkable fortitude the hot summer days. How refreshing the bright, green groves of cottonwoods must have been to the early western travellers as they approached the mountains after their long journey over the parched deserts!

With the latter and ascending farther up the mountain streams is the Black Cottonwood (Populus trichocarpa).* It is a tree of more regular form with many ascending branches and broad crown. The lilac-like leaves are dark green and shining above but whitish beneath. It is often called Balm or Bal-

\footnotetext{
* Grinnell in his Biota of the San Bernardino Moun. tains records the occurrence of a cottonwood in Fish Creek Canyon from 7200 to 8000 feet altitude, which is a variety of the $P$. trichocarpa. "The leaves were very much larger and fewer in number, and there was a far greater amount of balsam in the winter buds, so that the unfolding leaves were extremely sticky with it. The air in the vicinity was strongly charged with the characteristic odor far more than with trichocarpa. The trunk was larger in proportion to the height of the tree, smooth barked, and mostly green." A narrow-leaf variety ( $P$. trichocarpa VAR. ingrata) is found in the upper Santa Ana Canyon at the mouth of Nork Fork.
} 
sam because of the fragrant gummy buds which, especially in spring, fill the air with odorous sweetness.

According to Sudworth, the so-called "bee glue" with which honey bees fasten their honey combs in hives or in the hollows of trees, is gathered by bees from the buds of the cottonwoods.

The Quaking Aspen (Populus tremuloides), so familiar along Sierran streams, is found in but one place in Southern California, and this at Fish Creek, north of San Gorgonio Peak at 7000 to 7600 feet altitude. The little groups of dainty trees with roots planted along the waters of the vivacious, melodied mountain stream are a pretty sight to behold. It is well worth a special trip to see them.

Small groves of the narrow-leaved cottonwood (Populus angustifolia) occur along the Upper Santa Ana from 6100 feet up nearly to Big Meadows. They are mostly undersized trees. 


\section{The Yellow Willow}

Salix* lasiandra BENTH.

Along the upper Santa Ana river, this willow grows to a large tree. It is not listed by Hall among the willows of the San Jacinto Mountains. It is sometimes called Black willow on account of the color of its bark. "The leaves deep yellow-green at maturity and about $4 \frac{1}{2}$ to 5 inches long, are shiny on their upper surface, whitish beneath, the large mid-ribs reddish yellow." - SUdworth.

*Salix-From Salio, L. to leap or spring-from quickness of its growth.

Certain other willows like Salix laevigata BEBE, and Salix lasiolepis BENTH, and their varieties which are found along streams or around cienagas in the higher mountains, occasionally attain the proportions of trees, especially in favorable locations, but inasmuch as their exact identification is often very difficult and doubtful even under the critical study of experts, it has been deemed inexpedient to deal with them here. Those who desire to study the willows further will do well to consult Sargent's monumental work entitled, "THE SILVA OF' NORTH AMERICA." 


\section{WHITE ALDER}

Alnus rhombifolia NUTT.

Almost all the lower mountain streams are fringed with alders. They huddle so closely along the water borders that when storm freshets come they find themselves almost knee-deep in water and if the flood waters are too high and swift many of the less deeply rooted lose their footholds and are then carried by the torrents ruthlessly down stream. Wind storms, too, play havoc with their tall, slender trunks, and too often they fall like tall grass before the uproarious blasts, leaving the stream beds cluttered and choked with prostrate forms.

The alders are of great value as a stream cover since they appreciably reduce the amount of evaporation. Being found only on living streams that are permanent, they are reliable signs to the traveller of the presence of water. The Indians used a decoction of the astrin- 


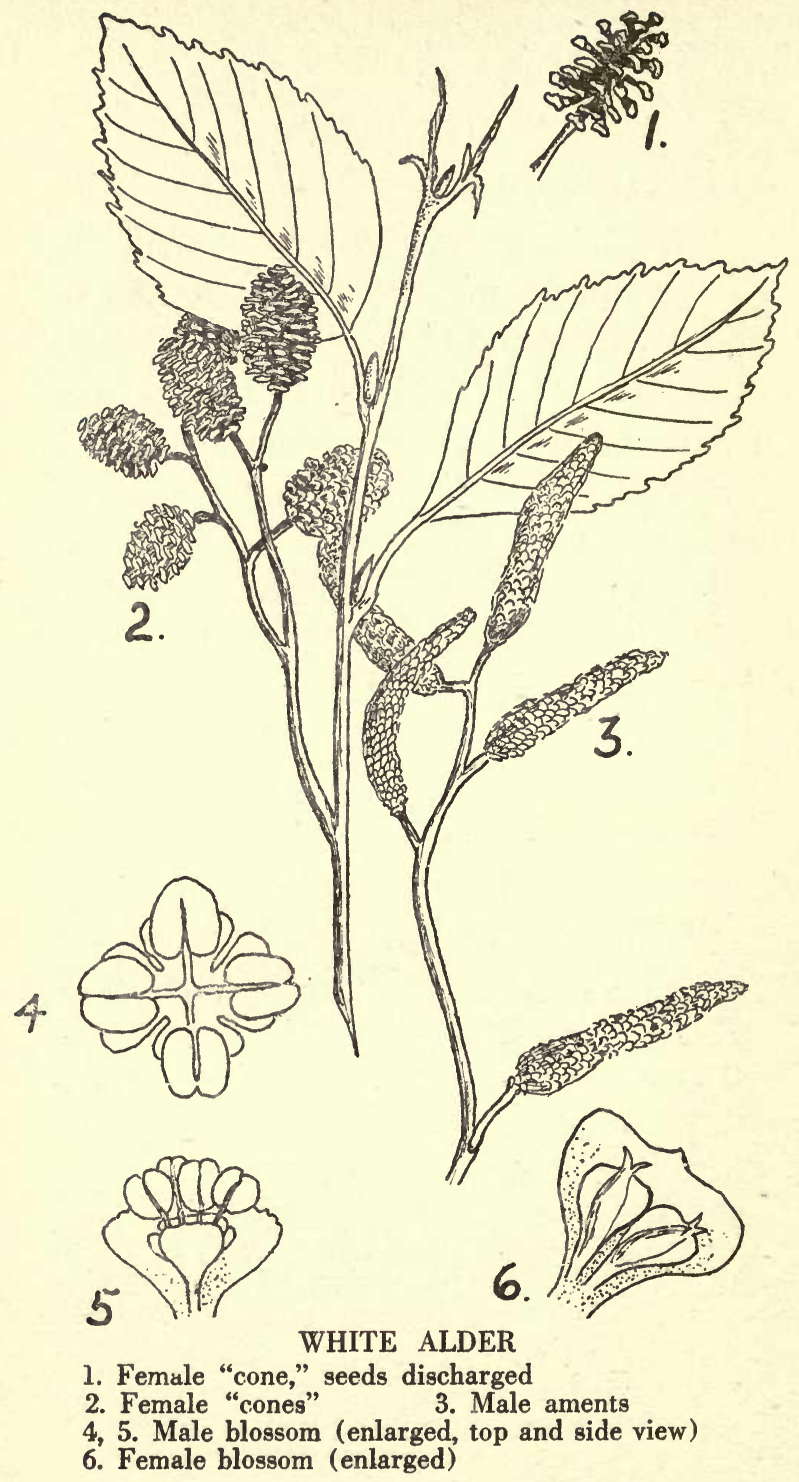


gent bark to produce vomiting and to check hemorrhage of the lungs.

About the bases of the alders and up in the oaks and willows you will find the conspicuous stick houses of the Mohave wood rats (Neotoma fuscipes mohavensis). They consist of dead and brittle sticks put together into steep stacks. Perhaps if you will poke into them gently with a stick the dainty brown-footed creatures will run out of their hiding and show you what clever tree scalers they are.

Sharing these nests of the wood rats are curious little beetles found nowhere else in the world. They are probably welcome guests since they live on the refuse of the nest. They are worthy of further study.

Often on the trunks of alders, willows and pine, and fir saplings are found rectangular, up and down incisions with narrow strips of bark between. These are made by the Sierra Sap-suckers. From the lower ends of the newly-made 
grooves the birds drink the oozing sap, taking it up with their short, brushytipped tongues. They will work on a single clump of willows for two or three years, leaving only when the group is exhausted and dead. 


\section{THE OAKS}

There are only four oaks in our mountains which may properly be called trees. Named in the order of their altitudinal distribution they are: the Scrub Oak (Quercus dumosa), the Wislizenus Oak (Quercus wislizeni), the Golden Oak ( $Q$. chrysolepis) and the California or Kellogg Oak (Q. kellogii).

The Scrub oak is a noticeable feature of the chaparral slopes where it forms dense thickets and grows more like a shrub than a tree. It is only in favorable, moist locations that it becomes arboreal. It is classed with the white oaks since it ripens its acorns the first season. Practically all the black oaks, of which the California oak is an example, ripen their nuts at the end of the second season. The Golden oak, while having a wood characteristic of the White oak, produces its acorns also in two seasons. 


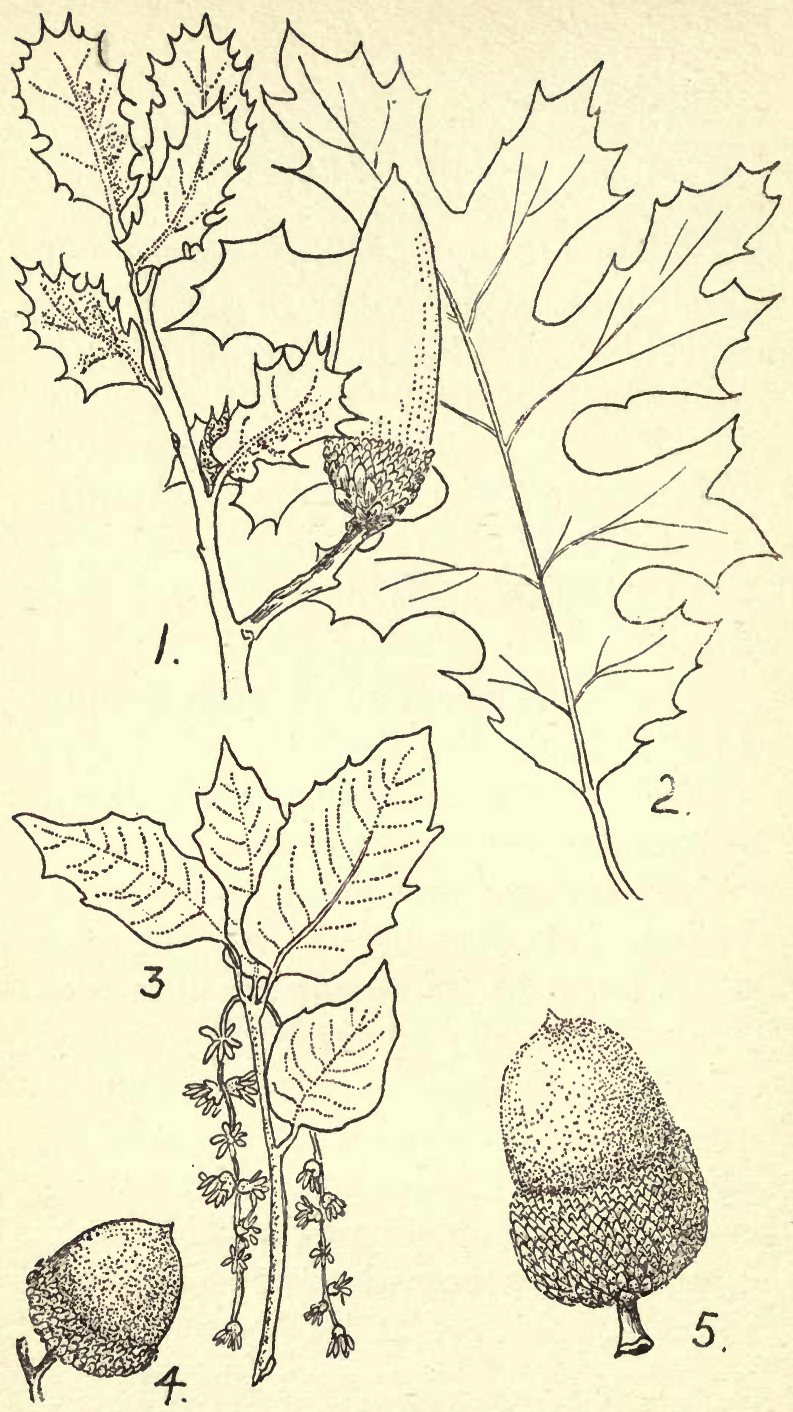

THE OAKS

1. Scrub Oak

2. Kellogg Oak
3. Golden Oak with male blossoms 4. Acorn of Golden Oak 5. Acorn of Kellogg Oak 
The Wislizenus Oak invades our mountains and composes a considerable portion of the upper chaparral growth (5000-7000 feet). Its leaves are all plane; lustrous green above, pale- or yellowish-green below, entire or toothed. The acorns are narrow, long and deepcupped.

In the interior valleys of Central California the Wislezenus Oak grows to a large, spreading, dense-crowned tree 40 to 60 feet high. In our region it seldom grows over 20 feet high (usually 5 to 10 , the scrub form being considered a variety (var fructescens Engl.). It generally occurs in small, rather opengrowthed clumps mingled with Scrub Oak or alone. Its branches are not so stiff, rigid, and thorny or so intricately and closely mingled as those of the Scrub Oak, and its leaves are a decidedly more lively green and less leathery looking, thus distinguishing itself from the latter tree. Acorns of the Wisle- 
zenus Oak mature in two years while those of the Scrub Oak ripen the first season.

Dr. F. Wislezenus, after whom the oak was named, was a botanist of German birth who travelled extensively in the Southwest.

The best field marks of the Golden oak are the golden yellow powder which covers the underside of the young leaves, and the golden fuzz-covered cups of the acorns, hence the specific term chrysolepis. "It is the only one of our trees which possesses immunity from wanton attack. Save for a definite purpose no one meddles with it, its local name, iron oak, being well merited."

The California oak grows at an elevation of about 5000 feet and is a prominent tree of the yellow pine belt. The general, graceful, aspiring form of the tree, and the deeply cleft leaves at once distinguish it from the other three oaks. It is our only deciduous-leaved mountain oak. 
It is to this tree that the Southern Indians look for the best acorns for meal-making. Rivaling in picturesqueness the pinyon gatherings among the desert Indians are the acorn hunts of the valley and mountain dwelling Indians found nearer the coast. When the lovely golden days of late October come and the ground lies thickly strewn with scarlet, frost-tinted leaves and the rich brown nuts of the oaks, parties of two to a dozen Indians mounted on ponies and followed by Indian dogs, make their way up the steep trails to the oak groves. If the rancherias are far from the nutting orchards pails, kettles, and other necessities for making camps are fastened to the saddles and several days are spent in the open, the length of the stay depending largely upon the rapidity with which the chattering squaws and children fill the sacks and burden baskets with acorns. Since acorns which have been on the ground a few days soon spoil with mildew, only 
the freshly fallen nuts are gathered. When the nut sacks are full the ponies which have been tethered close to the camp are again saddled and the merry, gaily dressed party makes its way to the villages below.

The acorns are soon shelled, stored in bags and hung high on the rafters of the wickiup or stored in enormous baskets, perched on platforms or bowlders out of doors and out of the reach of rodents. From time to time as they are required for food they are taken down and ground in a mortar to a very fine flour or meal. This is placed in a porous basket and warm water slowly poured over and through the meal until the bitter tannin is leached out. The process requires about four hours. Once prepared the meal is immediately cooked into a mush and consumed the same day. The Indians are very fond of it. Personally I cannot say it is unpleasant eating. The prepared mush has a reddish appearance and a rich nutty flavor and is con- 
sidered good eating by many white settlers when served with cream and sugar. Its food value is exceptionally high and the Indians all put on weight during the acorn season. Some students claim the rotund form of the California Indian is due to the constant eating of acorns for so many generations.

The Indians, woodpeckers and squirrels are not the only heavy consumers of acorns. The band-tailed pigeons, whose hooting call at eventime is so familiar to mountain travellers, eat acorns in large numbers. They swallow them whole, shell and all, relying upon the action of their powerful digestive juices to reduce them to absorbable form. The crops are often enormously distended and give the birds a peculiar stuffed appearance. How they can swallow such enormous acorns as those of the golden oak which are sometimes almost an inch in diameter and half again as long is almost beyond comprehension, and yet the amazing feat is performed. 
The oaks and the roses seem to have been specially chosen by the gall-making insects for home-sites. Any day's hunt will reward you with a half dozen forms each as individual and curious as can be. Most familiar of all are the oak "apples" so long prized by the ancients as a remedy in disease. These abnormal growths so rosy and round are often so numerous as to make the injured tree appear laden with fruit. They are due to the irritation of the plant tissues by the tiny larvae of Cynipid gall-flies. By some extraordinary and curious instinct the female selects certain sites most adapted for the production of the gall and with her awl-like ovi-positor pierces the tender growing tissues of the leaf or twig and there lays her eggs. In two or three weeks tiny footless larvae are born and begin to feed upon the sap of the vascular plant tissue in which they lie embedded. Then with the salivary secretions and physical irritation produced by the larvae as the exciting cause, the 
gall begins to grow, and never ceases its abnormal development until the larvae reach their full growth. Upon maturing of the larvae, the gall begins to dry up and harden, thus forming a snug house for the insects during their period of pupation. Later upon development into full grown flies, the tiny insects gnaw their way out of the dead galls to prick in new leaves and lay eggs for another life cycle.

These gall flies are tiny two-winged insects, the largest being not more than one-third of an inch long. Curiously, the individuals of some species are all females. An additional interesting feature is the fact that often in the same gall with the gall makers are other insect guests or parasites. These "degenerate loafers," are often present in amazing numbers and though they have done nothing in the making of the gallhouse, feed upon the sap and enjoy all the securities of the home of the host. 
Other insects which are closely associated with the oaks and which may well invite our interest are the tiny leaf miners which make those curious winding, serpent-like markings and blisterlike blotches on leaves by eating out the spongy tissue just beneath the leaf-skin. These little galleries which vary in shape according to the species of the miners inside, are made by small, white, much flattened, wedge-headed grubs of teneid moths. Now you will often notice near the end of the miner's tunnel a small enlargement which looks like a serpent's head. This marks the point at which the caterpillar changed to a pupa. In some cases you will find a hole showing where the larva came out of his mine and went to the ground to pupate. Many of the Tineids hibernate in the fallen leaves, in which they pupate and then transform into adults the next summer.

The Tineids are our smallest moths and include such injurious species as the clothes moths and carpet moths. Near 
relatives of these are the Tortricids or Leaf-rollers which roll or fasten up leaves in curious forms. A leaf-roller of very peculiar interest because of the queer pyramidal shelter it produces works on the young leaves of the California Laurel. The leaf is folded and the edges fitted together with such nicety that the larva's dwelling place must ever remain a monument to insect artisanship.

On the trunks of the Kellogg Oaks are often found great round excrescent growths which are the result of the trees' effort to seal over the stubs of dead, broken limbs. The process of covering begins at the base of the stub and the laying on of layers of tissue often continues until the dead wood is entirely engulfed in living tissue. Even after this isolation of unsound wood is accomplished the abnormal tissues often continue to grow, layer after layer of wood being laid on, until occasionally 
some of the grotesque and peculiar outgrowths are almost the size of barrels.

Live Oaks (Quercus agrifolia), stragglers from the broad, lowland valleys, are occasionally found in the lower canyons. They may be distinguished from the Golden Oaks by the fact that the leaves, always toothed, are convex on the upper surface.

"The California Scrub Oak," says Sudworth," unquestionably varies more than all our other oaks in the form and size of its leaves and acorns. No sort of satisfactory harmony can be established between the perplexing phases of its development, and one is likely to be hopelessly confused without a most comprehensive field study of the bushes and small trees belonging to this species." One of the best field marks is the tuberculate scales of the acorn cup. The tubercles are often so regular "as to suggest a quilted cushion." 


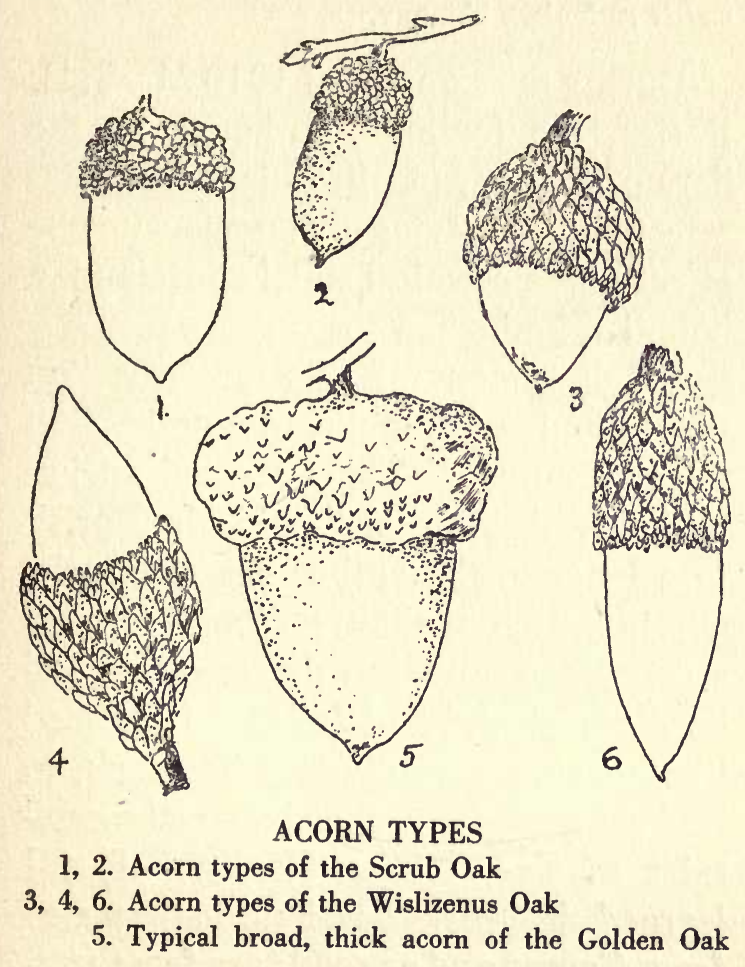




\section{Palo Blanco OR HackBerRy}

Celtis reticulata TORREY.

During the summer of 1919 Mr. S. B. Parish, the foremost authority on the flora of Southern California, became interested in verifying a statement to the effect that a certain Daniel Cleveland, a botanist, had some forty years ago collected specimens of this rare tree "on the summit of Laguna Mountain, San Diego County." "This seemed an improbable place to me," said Mr. Parish in a letter to the author describing the trip in search of the tree, "and, indeed, an effort to re-discover the tree there had been made, and had failed. It seemed like hunting a needle in a haystack, to find a single tree in the chaparral mountains of San Diego County. But I learned that Mr. Cleveland had started from Campo and as roads are few there-

The name celtis was used by Pliny for an African Lotus tree but was taken up by Linneas, following Tournefort for the trees with which it is associated in modern times.-Britton. 
abouts, by following his route I had little difficulty in finding Cleveland's identical tree, which people there say is the only one in all the region.

"There are about a dozen trunks, 2-6 inches in diameter, in a close clump, appearing as if they might come from a single underground stump; the tops are interlocked, forming a clump 15 feet high and 25-30 feet spread. The place is Thing's Ranch, 15 miles from Campo."

The alternate leaves of Celtis are thick and leathery, rough (sand-papery), "often covered with wart-like galls" and strongly netted-veined. They are dark green on the upper sides and pale yellowish green beneath. The fruit is orange-red when mature and about as large as a pea. The small flowers are greenishyellow and are borne on slender stems springing from the leaf-axils. Some of the flowers have only male organs while others are perfect, that is, they have both male and female organs.

This Celtis occurs in New Mexico, Nevada, Southern Utah, in California (western rim of the Colorado Desert) and in Lower California (San Julian Canyon and Cerros Island). 


\section{The CALIFornia LAUREL}

Umbellularia californica NUTT.

The California Bay is a close relative of the Sassafras of the Eastern United States and like it is a lover of damp soils and clings to the cool stream borders. The deep, green, willow-like leaves are as glossy as satin and exceedingly rich in an oil whose spicy fragrance perfumes the air for considerable distances about the tree. The small greenish-yellow flowers appear from January to April, in small clusters at the ends of the branches.

"The native tribes roasted the nuts and used them for food, but apparently did not eat great quantities of them at a time, using them rather as a stimulant

- or condiment. As prepared by the Indians they are not merely edible but sweet as chestnuts."-Jepson. The oil has anti-septic and anesthetic properties and is useful as a flea exterminator. 


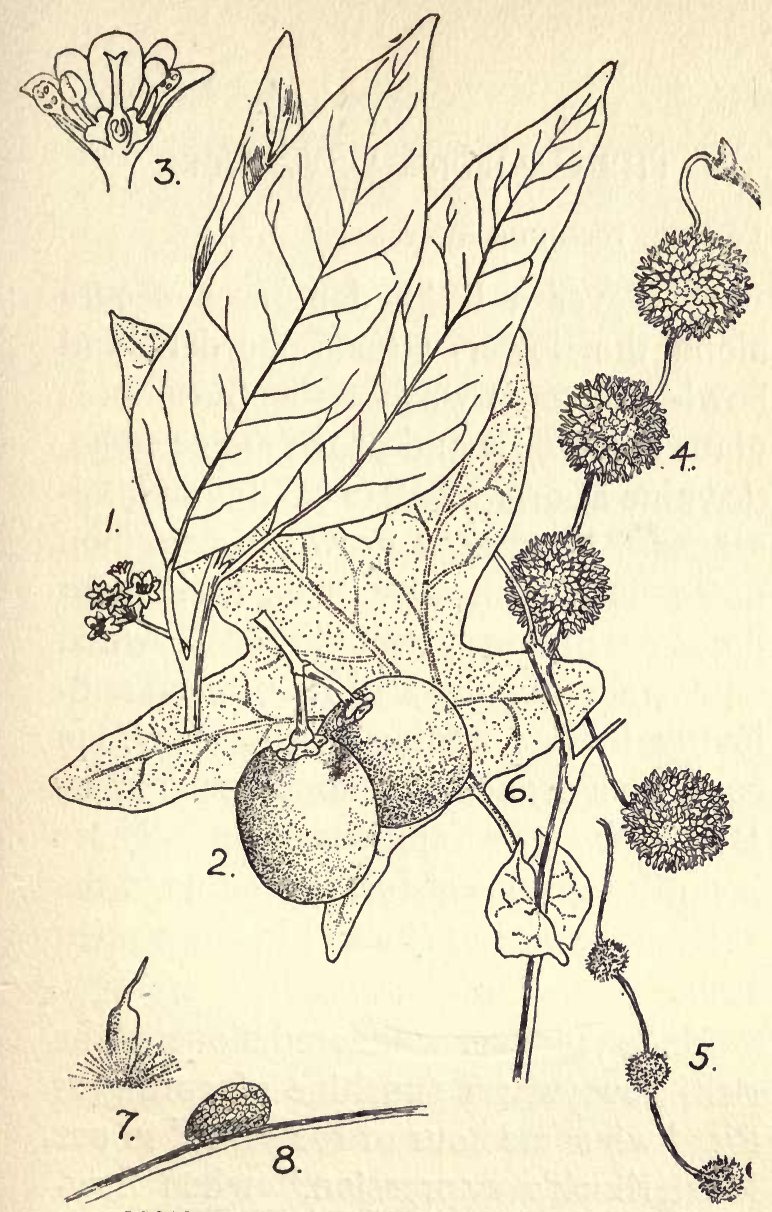

MOUNTAIN LAUREL AND SYCAMORE

1. Laurel leaf and blossom

2. Fruit

3. Flower dissected

4. Seed-balls of Sycamore

5. Male flower clusters

6. Sycamore leaf

7. Seed enlarged

8. Button to which seeds are attached 


\section{The California Sycamore}

Platanus racemosa NUTT.

Wherever a little dampness occurs along the lower stream borders and bowlder strewn washes the Sycamores plant their roots and prove their aesthetic value as ornamentors of canyon landscapes. Here they grow, as Audubon notes in his Journal, "with their giant limbs extending laterally" and crowned with graceful sprays of rich, green sunloving leaves, adding a charm to the countryside such as no other tree of Dame Nature's family can do. These beautiful divergent forms are due to the shifting nature of the soil in the stream beds.

Have you ever wandered alone in the rich, new, warm sunshine of spring at that "winsome hour of the year," to use Maeterlinck's expression," when flowers keep holiday," and enhaled the sweet aroma of the bronzed and bursting 
buds of the sycamore? Have you ever sat at eventide among the bowlders when all is bathed with the amber light of the setting sun and watched the bees as they flew about in tuneful circles, heard the outbursts of melody from happy birds perched among the branchesthen you know the sweet companionship of the sycamores.

The California sycamore belongs to the Plane-tree family and is not to be confused with the sycamore of the Bible (properly spelled sycomore), a tree which is closely allied to the common fig. (Sycomore means fig-mulberry).

The flowers-male and female-occur on different parts of the same tree. Both hang in ball-like clusters, the male groups being the smaller. The dense heads of fruit are made up of numerable nutlets at whose bases are circlets of many long, stiff hairs. These fruit clusters of two to seven heads are artistically arranged on pendent stems and persist until the following spring. 
The flower clusters, according to Evermann, are greedily eaten by the bandtailed pigeons, as many as thirty-five of these ball-like clusters having been found in the crop of a single bird.

During the period of growth the winter buds are neatly hidden away in the hollow bases of the leaves and only when the leaves fall do they get their first peep into the world of light. And have you ever noticed the little broad, frilled leaf-stipules which like little capes encircle the graceful angular stems just beneath each leaf? 


\section{CURL-LEaf oR Mountain MaHogany}

Cercocarpus ledifolius NUTT.

On the high, rocky ranges on the desert side of the San Bernardino, San Jacinto and San Gabriel Mountains, the Mountain Mahogany takes on the form of a small, angular-stemmed tree. It has wood almost as hard as the ironwood of the desert (Olneya tesota), and small linear, smooth-margined, revolute, leathery leaves adapted to resist the intense heat and dryness of its home. Most conspicuous of its characters and one which gives the genus Cercocarpus its name is the long, stiff, plumy, twisted, tail-like flower style which is adherent on the hard one-seeded fruit. At times of seed dispersal these hairy forms are so thick as to give the tree an appearance of being covered with thousands of tiny feathers.

Because of its extreme hardness and resistance to decay, the Indians and 


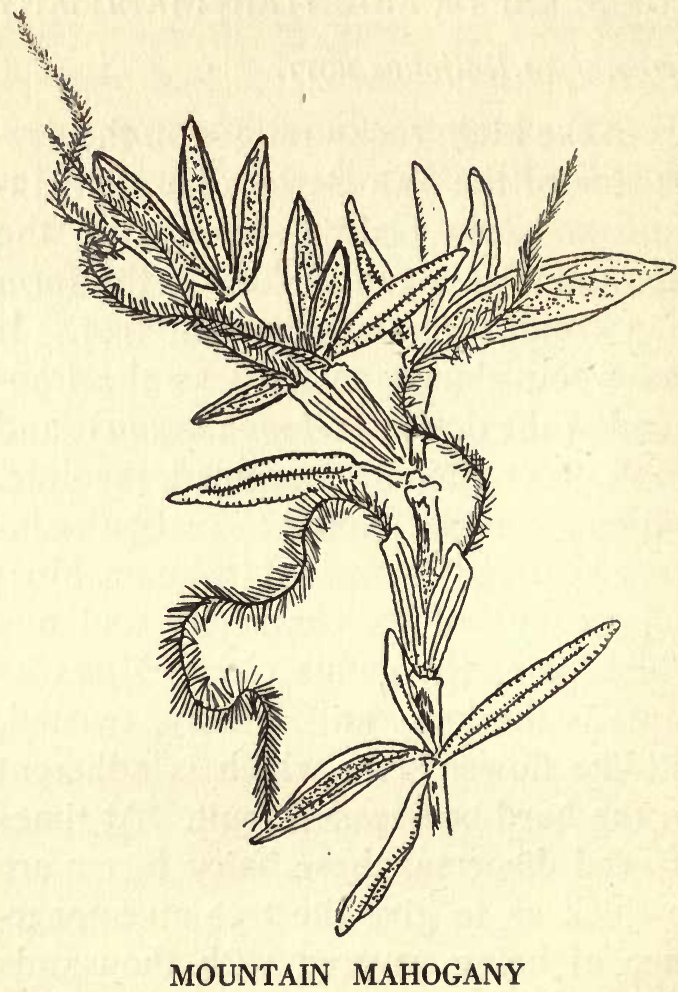


early settlers made much use of the wood in the making of simple implements of agriculture, such as grubbing sticks and tool handles. It makes good, although crooked, post timber and is a most excellent firewood.

The Birch-leaf Mahogany (Cerocarpus betulaefolius) conspicuous also because of its feathery-tailed fruits, should not be confused with the above. It may be distinguished by its wedge-shaped leaves which are toothed at the broad, upper end, and distinctly veined on both surfaces. Very tall specimens are found below Forest Home in Mill Creek Canyon. While attaining the height of small trees they are architecturally shrubs. 


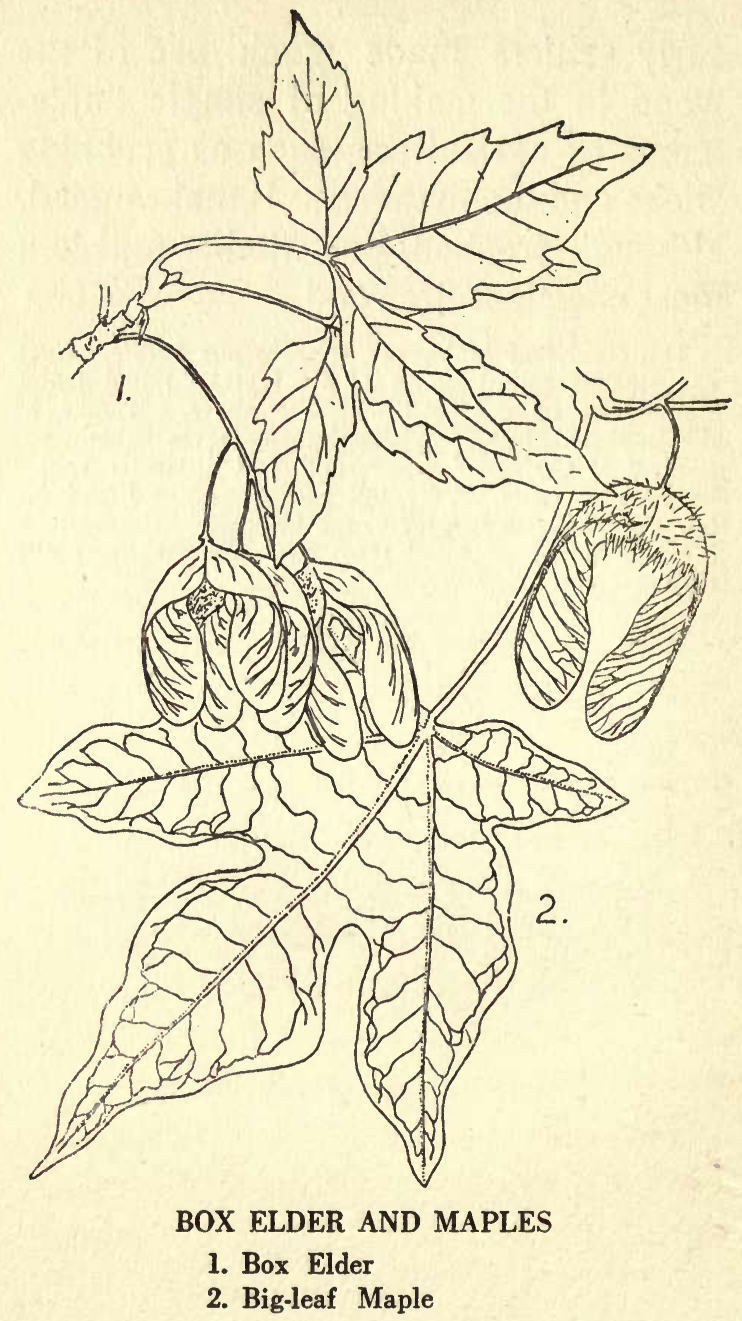




\section{BOX ELDER AND MAPLES}

Neither theBoxElders nor Maples are found plentifully within our region. The first named tree (Acer Negundo LiNN. var. californicum) occurs occasionally along streams in the San Jacinto and San Bernardino Mountains. (Locally abundant along Potato and Edgar Canyons). It is not the same as the Box Elder of the Mid-Western United States, but a variety.

The Black or Big-leaf maple (Acer macrophyllum), generally occurs as a solitary tree in our mountain canyons in dark, damp, secluded spots. Its large, dark, deep-lobed leaves measure 4 to 10 inches across. The thick bark is often very rough with long furrows. The tree forms a spreading crown and often grows very tall. The mountaineers have made sugar from the sap.

The yellowish or greenish flowers of all the maples are fertilized by small, short-tongued, lapping insects which 
congregate in great numbers about the open flowers with their unconcealed nectaries. The long-tongued bees and butterflies seldom visit them, well knowing that the sweeter, surer supplies of nectar are hidden in deeper and more showy flower-cups.

ACER, L., pointed, its light hard wood being used to form javelins. The English name is of uncertain origin. 


\section{WESTERN FLOWERING DOGWOOD}

Cornus Nultallii AUdubon.

For rich and varied autumnal color beauty surely the lovely Dogwood takes the prize. With the first touches of frost, the bright, soft, green leaves begin to color and then each succeeding day sees the rich hues doubled and trebled until every tree is a blaze of scarlet glory.

In the spring, especially in early May, these same trees were covered with numerous greenish blossom heads, each surrounded by six white showy bracts, so that the inflorescence is often 3 to 5 inches across. The masses of creamy blossoms banked against the delicate green of the ferns in the deep canyon shade is most striking - a sight to reward the mountain traveller at this season. It is frequent in the lower Yellow Pine belt, being especially abundant in the deep moist canyons opening up

CoRnus is the ancient Latin name for horn; in reference to the hardness of the wood. 


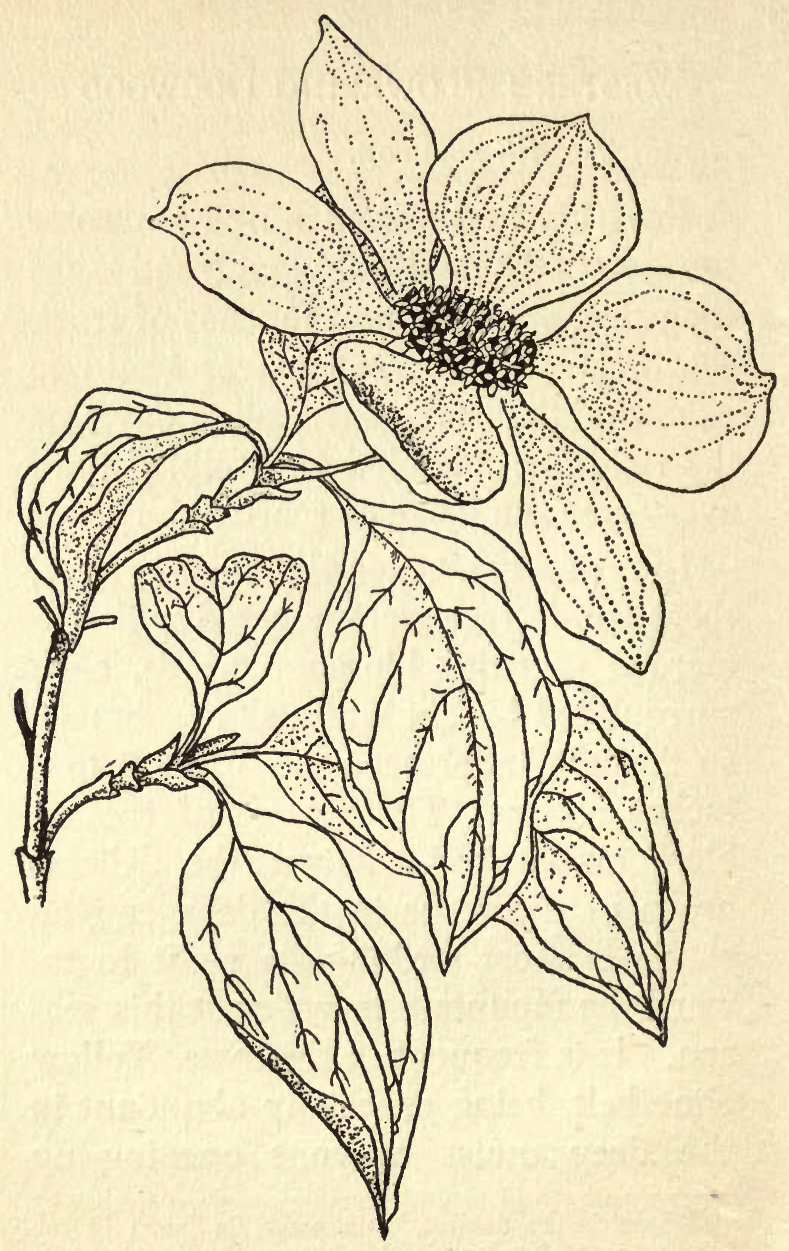

MOUNTAIN DOGWOOD 
toward Little Bear Lake. In the San Jacinto Mountains it is found in Dark Canyon. Though often shrub-like in form it frequently grows to a fairly good sized tree.

The fruits are shining red berries, arranged in dense clusters at the ends of the twigs. The fruit pulp surrounding the hard-shelled, one or two-seeded stone, is thin and dryish.

While several explanations are put forward for the origin of the name Dogwood the most probable asserts that originally this tree was called Dagwood (daggen L.- to pierce + wood), since it was used in the making of butcher's skewers. This use is further reflected in its common names such as prickwood and skewerwood. Through corruption by those not understanding this allusion it has come to its present form.

Since dogwood is uncommonly free from silex or other gritty substances, watchmakers use it for making pegwood 
for cleaning pivot-holes of watches. Its toughness and hardness insures it from breaking off in the finest pivot-holes. For the same reasons opticians find it valuable for removing dust from small, deep-seated lenses. 


\section{THE ASH}

Fraxinus oregona NUTT.

Some day when on your tree hunt you will wander down some sun-parched stream bed leading to the desert and there you will find the Ash trees growing. If it is winter you will find them leafless and at their best. And you can then study the endless ramifications of their branches and get the charm of form instead of color. Nature is fertile in her devisings and no two trees can be alike. The best time to catch the beauty of these tree outlines is at the evening hour. Looking down some westward sloping canyon out upon the silent and colorful desert you see the bright lights behind them as they stand in dark relief against the gold-burnished, maroonstreaked sunset sky.

The Oregon Ash grows best in the rich, moist, bottom lands along the rivers of Southwestern Oregon and Northern

FRAXINUS, from franger L., to break, the wood being brittle. The English Ash is an old Saxon word. 


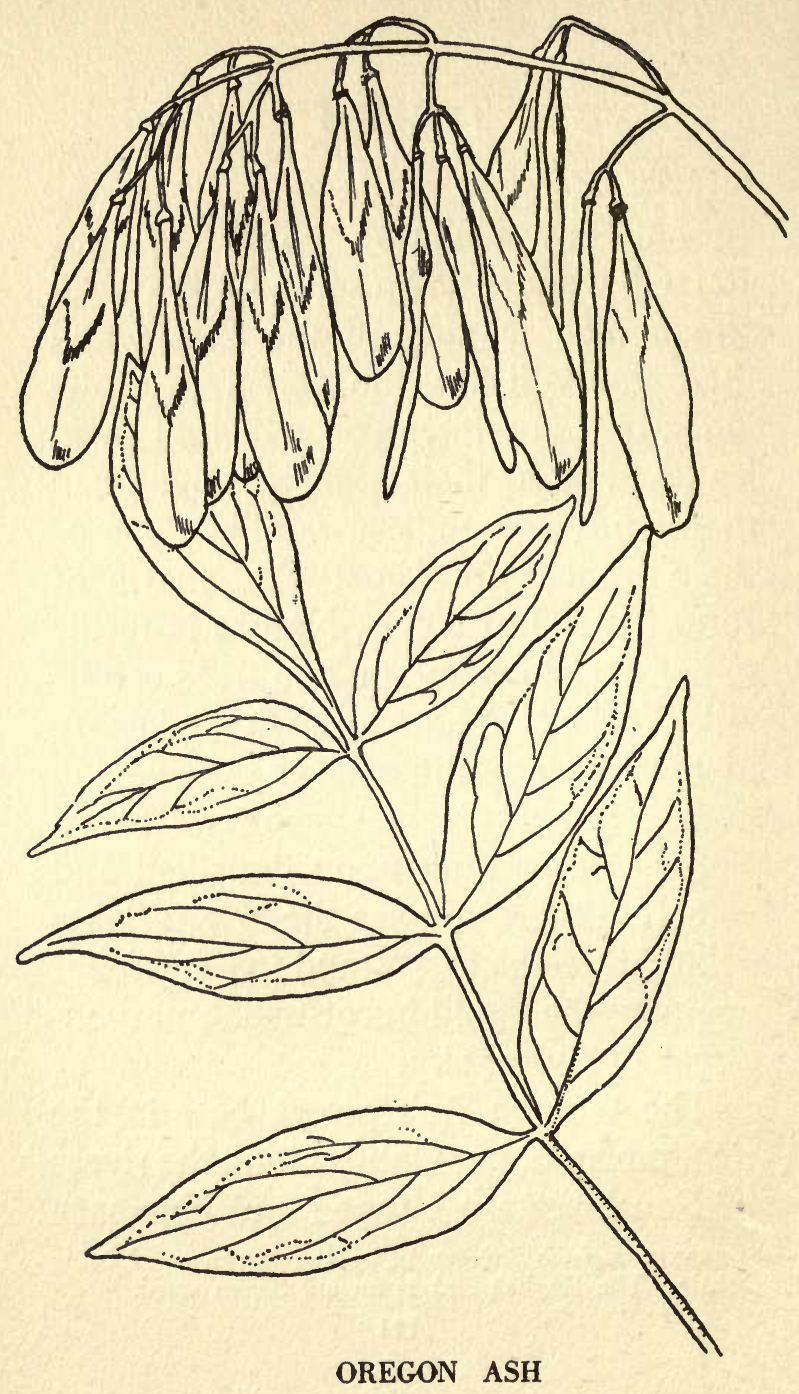


California. It occurs sparingly along streams in both the Sierra Madre and San Bernardino Mountains. It is a tree of rapid growth and has commended itself for street planting in many parts of the Pacific coast. The unique leaves and inconspicuous blossoms serve to differentiate it from all other trees of its range in our southern mountains. 


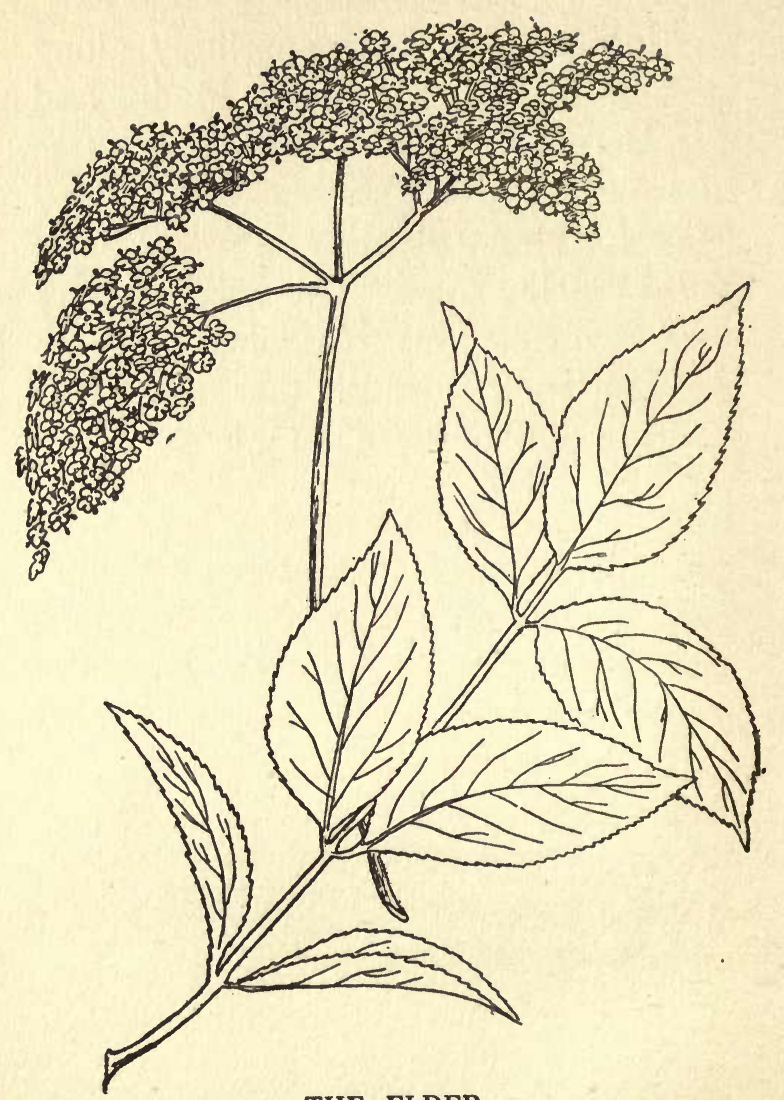

THE ELDER 


\section{THE ELDER}

Sambucus glauca* NUTT.

The Elder is a member of the Honeysuckle family and conspicuous for the great crops of greenish-white or pale blue berries produced in late summer. Though rather insipid they are esteemed highly by many housewives as a filling for pies. Many of the Indians will not use them raw, claiming that they often produce severe sickness. This, however, is not the fault of the fruit, but is due rather to a small red spider which lives in the fruit cluster and which is unknowingly eaten with the berries. The dark, roughly fissured bark, steeped in hot water, is used as a remedy in dropsy, while the tea from the flower is said to be efficacious as a fever remedy.

* Sambucus-In Greek Sambux-from which a musical instrument was made-sackbut. Glauca means, covered with a bloom or fine white powder of wax that rubs off-referring to the glaucous berry. 


\section{MADRONO}

Arbutus menziesii PURSH.

The Madrono is a close relative of the familiar manzanita. It is a striking evergreen tree with deep red bark and large, glossy, green leaves and once seen is not easily mistaken for any tree of its range. The few trees found in Southern California are restricted to small groups near the Mount Wilson and Sturdevant trails at an altitude of about 3000 feet, in Las Tunas Canyon in the Santa Monica Mountains, and the Palomar Mountains above Pauma. 


\section{N D E X}

Abies concolor, 61

Acer, 105

Alder, 77

Alnus rhombifolia, 77

Arbutus menziesii, 116

Ash, 111

Aspen, 75

Big-Cone Spruce, 57

Birch-leaf mahogany, 103

Box Elder, 105

Cedar, 65

Celtis reticulata, 94

Cercocarpus, 101

Cornus nuttallii, 107

Cottonwoods, 73-75

Coulter Pine, 21

Digger Pine, 27

Dogwood, 107

Elderberry, 115

Fir, 61

Four-leaf Pine, 45

Fraxinus oregona, 111

Hackberry, 94

Jeffrey Pine, 35

Juniper, 69

Laurel, 96

Libocedrus, 65

Limber Pine, 47
Madrono, 116

Maple, 105

Mahogany, 101

Oaks, 81

Parry Pine, 45

Pinyon, 9

Pinus attenuata, 41 coulteri, 21

flexilis, 47

jeffreyi, 35

lambertiana, 51

monophylla, 9

murrayana, 13

ponderosa, 29

quadrifolia, 45

sabiniana, 27

Platanus, 98

Pseudotsuga, 57

Quercus agrifolia, 92

californica, 84

chrysolepis, 84

dumosa, 81, 92

wislizeni, 83

Sambucus glauca, 115

Salix, 76

Sugar Pine, 51

Sycamore, 98

Tamarack, 13

Umbellularia, 96

Western Yellow Pine, 29

Willow, 76

Wislizens Oak, 83 

THIS BOOK IS DUE ON THE LAST DATE STAMPED BELOW

\section{AN INITIAL FINE OF 25 CENTS} WILL BE, ASSESSED FOR FAILURE TO RETURN THIS BOOK ON THE DATE DUE. THE PENALTY WILL INCREASE TO 50 CENTS ON THE FOURTH DAY AND TO \$1.00 ON THE SEVENTH DAY OVERDUE.

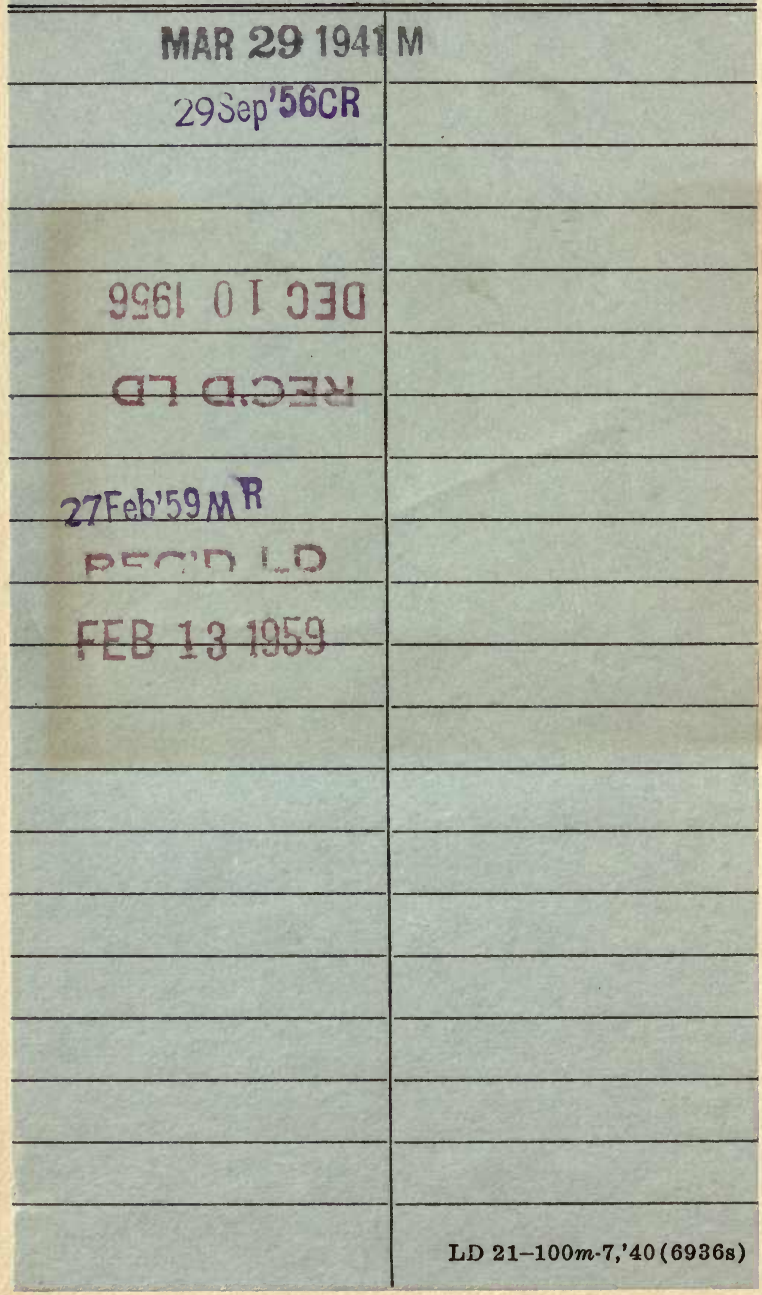


YB 12564

,

551394

UNIVERSITY OF CALIFORNIA LIBRARY 
